\title{
Problems and Progress in Glycopeptide Synthesis
}

\author{
糖ペプチド合成における問題と進展
}

\author{
Nakahara, Yoshiaki \\ Department of Applied Biochemistry, Institute of Glycotechnology, Tokai University, \\ Kitakaname 1117, Hiratsuka, Kanagawa, 259-1292 Japan \\ FAX: 81-463-50-2075, E-mail: yonak@ keyaki.cc.u-tokai.ac.jp
}

Key Words:chemoenzymatic synthesis, emmprin, glycopeptide, glycophorin A, solid-phase synthesis

\begin{abstract}
The contribution of the $\mathrm{N}$ - and O-linked oligosaccharides to a variety of glycoprotein-mediated biological phenomena has recently attracted broad interest. Synthetic glycopeptides are needed as the tools to ascertain the biological roles played by the oligosaccharides. A series of investigations on glycopeptide synthesis thus far made in our research group is presented in this minireview. In order to facilitate the construction of $\mathrm{N}$ - and O-linked oligosaccharides, we have been employing a benzyl group for protection of the hydroxyl groups. Having thus prepared glycosylated amino acid building blocks, we tackled the solid-phase synthesis of glycopeptides. Syntheses of the part structures of such biologically important glycoproteins as glycophorin, leukosialin, $\alpha 2 \mathrm{HS}$ glycoprotein, hCG, CD52, and emmprin are described.
\end{abstract}

要 約

最近糖タンパク質が関与するさまざまな生物現象への N-お よびO-結合型糖鎖の関わりが広く注目されてきている。その糖 鎖の生物機能を明らかにするためのツールとして合成糖ペプチ ドが求められている。このミニレビューではわれわれの研究グ ループでこれまで行ってきた一連の糖ペプチド合成研究を紹介 する。N-および O-結合型糖鎖を効率的に合成するためわれわれ は水酸基の保護基としてベンジル基を用いてきた。そのように 調製した糖アミノ酸ビルディングブロックを使って糖ペプチド の固相合成に取り組んだ。グリコホリン、ロイコシアリン、 $\alpha 2 \mathrm{HS}$ 糖タンパク質、 hCG、CD52 そしてエムプリンなど生物学 的に重要な糖タンパク質の部分構造の合成について述べる。

\section{A. Introduction}

The study of natural products has contributed enormously to advances in organic chemistry. Through studies in isolation and structural elucidation of novel molecules, HPLC, NMR, and MS technologies have uninterruptedly been improved. Enjoying the benefits of high-performance machines and advanced technologies in analysis, present-day researchers can gain access to such rare and/or complex biomolecules as polyether toxins from marine sources. Efforts have also been devoted to the total synthesis of those newly found compounds in order to prove the structures and to demonstrate ingenuity in designing efficient synthetic routes, new reactions and new reagents.

\section{A. はじめに}

天然物の研究は有機化学の発展に多大な貢献をしてきた。 新しい分子の単離、構造決定の研究を通して、HPLC、NMR そ して MS の技術は絶え間なく改良されてきた。高性能の機器と 先端的分析技術のおかげで、今日の研究者達は海産性ポリエー テル毒素などのような稀少かつ複雑な生物活性分子にも研究の 手を広げることができるようになった。新規に見つけられた化 合物の全合成にも努力がささげられてきた。それは構造を確認 するためであり、また優れた合成ルートや新反応、新試薬をデ ザインできる賢さを披瀝するためでもあった。合成化学者に

\footnotetext{
Abbreviations: All, allyl; Boc, $t$-butoxycarbonyl; Cbz, benzyloxycarbonyl; DCC, 1,3-dicyclohexylcarbodiimide; DIEA, N,Ndiisopropylethylamine; DMSO, dimethylsulfoxide; DMTST, dimethyl(methylthio)sulfonium trifluoromethanesulfonate; Fmoc, 9fluorenylmethoxycarbonyl; GPI, glycosyl phosphatidy linositol; HATU, O-(7-azabenzotriazol-1-yl)-N,N,N',N'-tetramethyluronium hexafluorophosphate; HBTU, O-benzotriazol-1-yl- N,N,N',N'-tetramethyluronium hexafluorophosphate; hCG, human chorionic gonadotropin; HMPB-BHA resin, 4-hydroxymethyl-3-methoxyphenoxybutyric acid benzhydrylamine resin; HOAt, 1-hydroxy-7-azabenzotriazole; HOBt, 1hydroxybenzotriazole; HOOBt, 3,4-hydro-3-hydroxy-4-oxo-1,2,3-benzotriazine; NMP, 1-methyl-2-pyrrolidinone (N-methylpyrrolidone); PfpOH, pentafluorophenol; TFA, trifluoroacetic acid; TfOH, trifluoromethanesulfonic acid; THF, tetrahydrofuran; TMSBr, trimethylsilyl bromide; TMSOTf, trimethylsilyl trifluoromethanesulfonate; WSC, 1-ethyl-3-(3-dimethylaminopropyl)-carbodiimide (water soluble carbodiimide)
} 
Trends in Glycoscience and Glycotechnology

Glycoprotein is another novel and challenging research target for synthetic chemists because of its biological importance and structural complexity. The role of the oligosaccharide attached to protein has often been described in connection with immunogenicity, cell adhesion, cancer metastasis and viral infection. However, the detail of the function remains unclarified due to the low availability of homogeneous samples from natural sources. In most biological processes that involve glycoproteins, the polypeptide parts in the protein may be the leading players whereas the attached oligosaccharide may play a supporting role. Therefore, the actual importance of oligosaccharide should be discussed on the basis of experiments with the whole glycoprotein molecule or the functional domain of glycopeptide. Since preparation of a glycoprotein with single glycoform by means of recombinant technology has been difficult so far, chemical synthesis may be a potent alternative to solve the problem of inaccessibility of homogeneous samples. In general, glycoproteins are too large to be chemically synthesized. On the other hand, the relatively small glycoproteins (up to $20 \mathrm{kDa}$ ) or parts of large glycoprotein (glycopeptides) will be accessible by chemical means. Such biologically significant molecules as cytokines and hormones are included in this category.

Glycopeptides with a long peptide chain (10-20 amino acids) are rapidly and efficiently prepared on resin by utilizing glycosylated amino acid building blocks with other amino acid units.

The solid-phase synthesis of glycopeptide began in 1981 when Lavielle et al. reported a GlcNAc-linked pentapeptide that was prepared by applying Boc solid-phase peptide synthesis (1). The Boc-based method requires substantially stronger acidic conditions for cleavage of the synthesized peptide from resin and for deprotection of the side chain functional groups. Liquid $\mathrm{HF}$ is commonly used. The conditions are apparently incompatible with the acid-labile glycosidic linkages present in the oligosaccharide of glycoprotein. Therefore, the Fmoc-based procedure, in which the $\mathrm{N}$-terminal protecting group is removed under a mildly basic condition, has been widely used for glycopeptide synthesis. Including the pioneering work done in the late 1980s by Paulsen, Kunz, and Otvos, Jr., the major topics in the solid-phase synthesis of glycopeptides were reviewed in a previous paper (2). Outstanding reviews focused on the synthesis of glycopeptides have also been written by other authors (39). In this article, our recent achievements in the synthesis of glycopeptides are demonstrated.

\section{B. Synthesis of $\mathbf{O}$-Glycopeptides}

$\mathrm{N}$-Acetylneuraminic acid (sialic acid) is important as a non-reducing end residue of oligosaccharides in glycoproteins as well as in glycosphingolipids. The syntheses of core class 1 O-linked sialo-di-, tri-, and tetrasaccharides were first demonstrated in 1988 and 1989 by Iijima and Ogawa (10-12). The
とって糖タンパク質もまたその生物学的重要性と構造の複雑さ ゆえに新たな挑戦しがいのある研究標的である。タンパク質に 結合しているオリゴ糖の役割はしばしば免疫原性、細胞接着、 ガン転移そしてウイルス感染などに関連して記述されてきた。 しかしながら、天然由来の均質なサンプルが得難いこともあっ てその機能の詳細は依然不明である。糖タンパク質が関与する 大部分の生物過程においてはタンパク質のポリペプチド部がそ の主役であり、附随するオリゴ糖はその支えの役割を演じてい るように思われる。したがってオリゴ糖の真の重要性を議論す るためには全糖タンパク質分子またはその機能性ドメインであ る糖ペプチドを用いた実験をもとになされるべきである。単一 のグリコフォームをもつ糖タンパク質を組み換え技術で調製す ることは現段階では困難なので、それに代わって化学合成が均 質なサンプルを得るための可能な手段となるだろう。一般に糖 タンパク質は化学合成するには大きすぎる。一方、 $20 \mathrm{kDa}$ 程度 の比較的小さな糖タンパク質や大きな糖タンパク質の一部分な らば化学的な方法で手に入れることができるだろう。サイトカ インやホルモンなど生物学的に重要な分子がこの範疇に入る。 10-20 アミノ酸からなる糖ペプチドは糖の結合したアミノ酸ビ ルディングブロックを他のアミノ酸ユニットと一緒に使うこと によって樹脂上で迅速かつ効率的に調製することができる。糖 ペプチドの固相合成は 1981 の Lavielle らにより報告された Boc 法による GlcNAc 結合型ペンタペプチド 合成にはじまる(1)。 Boc を基盤とする方法では合成ぺプチドの樹脂からの切り離し と側鎖官能基の脱保護にかなり強い酸条件を必要とする。通常 液体フッ化水素が使われる。その条件は糖タンパク質の糖鎖に 存在する酸に不安定なグリコシド結合とは明らかに相容れな い。したがって、緩和な塩基性条件で $\mathrm{N}$-末端保護基の除去が可 能な Fmoc を基盤とする方法が糖ぺプチド合成に広く用いられ てきている。1980 年代後半に Paulsen や Kunz そして Otvos, Jr. らによって行われた先駆的な仕事を含め、糖ぺプチドの固相合 成の主要なトピックスは以前の総説に示した(2)。糖ペプチド合 成についての優れたレビューが他の著者によっても著わされて いる(3-9)。ここでは糖ぺプチド合成におけるわれわれの最近の 成果を紹介する。

\section{B. O-糖ペプチドの合成}

N-アセチルノイラミン酸 (シアル酸) は糖タンパク質やス フィンゴ糖脂質糖鎖の非還元末端残基として重要である。1988 および 1989 年に飯島と小川はコアクラス 1 の O-結合型シアロ 2 糖、 3 糖、4 糖の最初の合成を示した(10-12)。この研究にお 


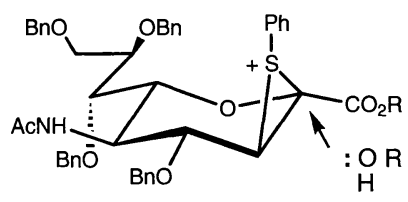

1: $\mathrm{R}=\mathrm{CH}_{3}$ 2: $\mathrm{R}=\mathrm{Bn}$

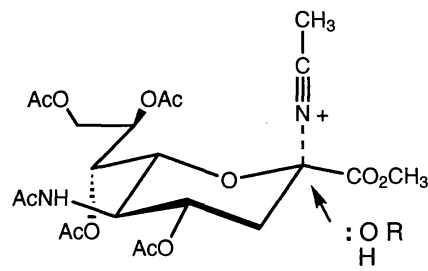

3

Fig. 1.

studies presented insufficiency of the stereoselectivity in glycosylation with a serine derivative. Introduction of the sialic acid residues was done with moderate efficiency by the conventional sialylation method. The glycoserines thus synthesized were inappropriately protected to be used as the building blocks for the synthesis of glycosylated oligopeptides.

In 1988 , two improved methods for $\alpha$-selective sialylation were developed by Riken (13) and Gifu groups (14), and have made important contributions to the development of ganglioside synthesis. (Fig. 1)

Riken's sialic acid donor (1), designed in a benzyl-protected form, also seemed useful for the synthesis of sialoglycopeptides. The choice of the protecting groups in the oligosaccharide moiety is crucial in order to achieve successful glycopeptide synthesis. Benzyl ether-based protection provides reactive intermediates in oligosaccharide synthesis, and the benzyl groups can be removed by hydrogenolysis under essentially neutral conditions. However, the deprotection procedure can not be applied when sulfur-containing amino acid residues are involved in the glycopeptides. In contrast, acyl protection gives a less reactive sugar, and the protecting groups are removed with a base. The base treatment sometimes gives rise to the concerns about epimerization at the $\alpha$-carbon center of amino acids and $\beta$-elimination of the substituents on serine and threonine residues.

In 1990 we stereoselectively synthesized a serine-linked sialyl Tn building block utilizing sialic acid donor $\mathbf{2}$ and achieved the first synthesis of sialooligopeptide, a tetrapeptide carrying trimeric sialyl Tn epitope (15). With a little modification on the protection of amino acid and the step for removing the phenylthio auxiliary, serine and threonine-linked building blocks were used for the synthesis of $\mathrm{N}$-terminal glycopentapeptides of glycophorin AM 7 and AN 8 (16). It was not long before the building blocks 9 and $\mathbf{1 0}$ for the most common disialylated tetrasaccharide were also synthesized and used for the synthesis of the N-terminal heptapeptide of glycophorin AM 11 (17-19). These synthetic sialoglycopeptides were ultimately deprotected by hydrogenolysis with a Pd catalyst in aq. $\mathrm{MeOH}$ or in aq. THF. (Fig. 2)

Based on the knowledge gained from these solutionphase experiments, we initiated the polymer-support synthesis
いてはセリン誘導体のグリコシル化における立体選択性が不十 分であった。また従来法を用いたシアル酸残基の導入も中程度 の効率であった。そして合成された糖セリンはさらに糖オリゴ ペプチド合成のビルディングブロックとするには不適当な保護 基の使い方であった。1988 年 $\alpha$-選択的シアリル化のための改良 法が二つ理研 (13) と岐阜大 (14) のグループによって開発され、 それらはガングリオシド合成の進歩に重要な貢献をしている(図 1)。

理研のシアル酸糖供与体 (1) は、ベンジル保護体としてデザ インされているものでありシアロ糖ペプチド合成にも有用であ ると思われた。糖ペプチド合成をうまく行うには糖鎖の保護基 の選択が重要である。ベンジルエーテルを基盤とする保護は糖 鎖合成において反応性の高い中間体を与え、ベンジル基は基本 的には中性の条件下で加水素分解により除去される。しかしな がら、糖ペプチドが含硫アミノ酸残基を含む場合はこの脱保護 法は使えない。一方で、アシル保護基はより反応性に劣る糖を 与え、それは塩基により除去される。塩基による処理は時とし てアミノ酸 $\alpha$-炭素上でのエピメリ化やセリン、トレオニン残基 上での置換基の $\beta$-脱離の心配がある。

1990 年われわれはシアル酸供与体 2 を利用してセリンと結 合したシアリル Tn ビルディングブロックを合成し、シアリル Tn 3 量体を含むテトラペプチドの最初の合成を達成した(15)。アミ ノ酸の保護とフェニルチオ補助基の除去工程に若干の修正を加 え、セリンとトレオニンのビルディングブロックをグリコホリ ンAM 7 とAN 8 の N-末端ペンタペプチドの合成に利用した(16)。 続いて、最も標準のジシアロ 4 糖ビルディングブロック 9 と 10 を合成し、グリコホリン AM の N-末端へプタペプチド 11 の合 成に用いた (17-19)。これらの合成シアロ糖ペプチドは最後に含 水メタノールか含水 THF 中でのパラジウム触媒を用いた加水素 分解によって脱保護した(図 2)。

液相における実験での知見をもとに、われわれは糖ぺプチド のポリマーサポート合成に取りかかった。ヒト $\alpha 2 \mathrm{HS}$ 糖タンパ 

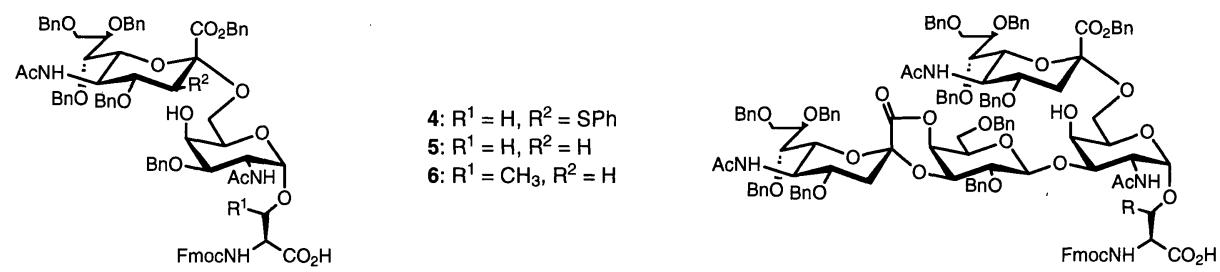

9: $\mathrm{R}=\mathrm{H}$

4: $\mathrm{R}^{1}=\mathrm{H}_{1} \mathrm{R}^{2}=\mathrm{SPh}$ 5: $\mathrm{R}^{1}=\mathrm{H}, \mathrm{R}^{2}=\mathrm{H}$ 6: $\mathrm{R}^{1}=\mathrm{CH}_{3}, \mathrm{R}^{2}=\mathrm{H}$

10: $\mathrm{R}=\mathrm{CH}_{3}$
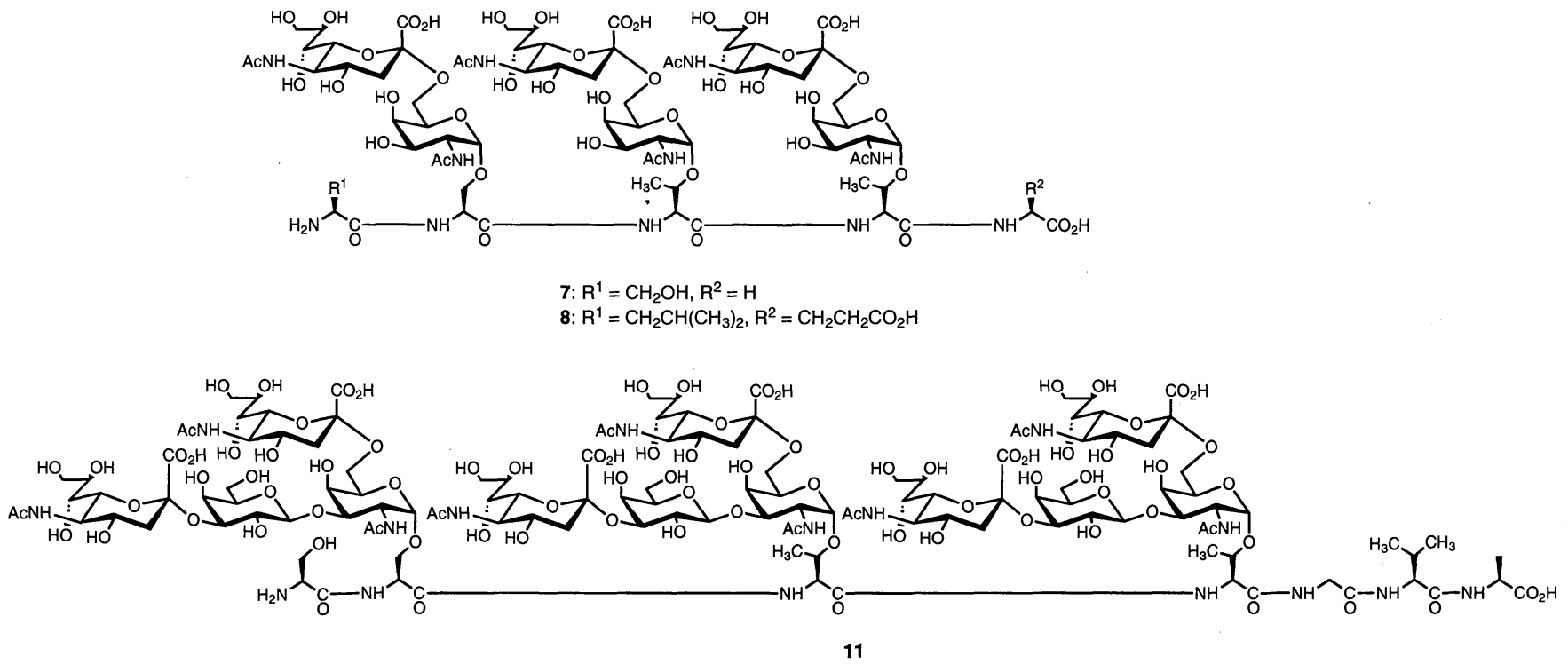

Fig. 2.

of glycopeptides. The B-chain of human $\alpha 2 \mathrm{HS}$ glycoprotein was chosen as the first target. The glycoprotein is a normal plasma globulin and is known to participate in bone mineralization, endocytosis, and opsonization. The subunit B-chain $\mathbf{1 2}$ is a heptacosapeptide glycosylated at $\mathrm{Ser}^{6}$ with Neu5Ac-Gal-GalNAc (core 1, sialyl-T antigen). Before the synthesis of 12, an asialo$\left[\mathrm{Ala}^{18}\right]$-analog 13 was synthesized by using Gal-GalNAc-linked serine building block 14. The C-terminal henicosapeptide ( $\mathrm{Val}^{7}$ $\mathrm{Val}^{27}$ ) was synthesized on the Wang resin according to the readymade Fmoc program of the peptide synthesizer, in which Fmoc amino acids activated with DCC-HOBt were sequentially added in NMP. N-Deprotection was performed with $20 \%$ piperidine in NMP. Then building block 14 ( 3 equiv.) was activated with the same activators and condensed with the resin-linked peptide by using a mechanical shaker for a prolonged reaction time $(64 \mathrm{~h})$. The five $\mathrm{N}$-terminal amino acid residues were condensed again with the automated synthesizer to complete the sequence. Cleavage of the product was performed with reagent $\mathrm{K}$ (aq. TFA and alkyl cation scavenger-based reagent) to give a complex mixture of glycopeptides (44\%) and the glycoserine unit-deleting peptide (56\%). HPLC and mass spectral analyses revealed that the former consisted of more than nine congeners derived by partial debenzylation. The combined glycopeptides were hydrogenated with a Pd-catalyst in aldehyde free aq. EtOH to produce 13 in $26 \%$ yield from the henicosapeptide-resin (20). One
ク質の B-鎖を最初の標的として選択した。この糖タンパク質は ヒトの正常な血漿グロブリンであり骨石灰化、エンドサイトー シス、オプソニン作用などへの関与が知られている。サブユ ニットのB-鎖 12 はペプタコサペプチドであり $\mathrm{Ser}^{6} に \mathrm{Neu} 5 \mathrm{Ac}-$ Gal-GalNAc (core 1, sialyl-T antigen)からなる糖鎖が結合してい

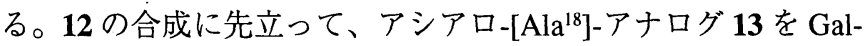
GalNAc が結合したセリンのビルディングブロック $\mathbf{1 4}$ を用いて 合成した。C-末端のヘンイコサペプチド $\left(\mathrm{Val}^{7}-\mathrm{Val}^{27}\right)$ をペプチド 合成機の既存の Fmoc プログラムにしたがってWang 樹脂上で 合成した。Fmoc アミノ酸を DCC-HOBt で活性化し NMP 中で 順次加えた。N の脱保護は NMP 中 $20 \%$ piperidine でおこなっ た。次にビルディングブロック $\mathbf{1 4}$ ( 3 当量) を同じく活性化し て機械的なシェーカーを利用して長時間 (64 時間) 摇することで 樹脂上のペプチドと縮合した。 $\mathrm{N}$-末端の 5 アミノ酸残基は再び 自動合成機に戻して縮合し配列を完成させた。生成物の切断は reagent $\mathrm{K}$ (含水 TFA とカチオン捕捉剤がベースの試薬) で行っ たところ、糖ぺプチド $(44 \%)$ と糖セリンユニットが久損したぺ プチド (56\%) の複雑な混合物を生じた。HPLC とマススペクト ル分析から前者は部分的に脱ベンジルされた九つ以上の類縁体 からなっていることが分かった。その糖ぺプチドを合わせてア ルデヒドフリーの含水エタノール中パラジウム触媒とともに接 
cause of the low yield in coupling of $\mathbf{1 4}$ was thought to come from the insufficient stirring of the solid and liquid mixture.

The synthesis of the native B-chain molecule containing sialic acid and cystein residues was next investigated. The necessary trisaccharide building block 15 was prepared via glycosylation of $\mathbf{1 8}$ with disaccharyl trichloroacetimidate $\mathbf{1 7}$. The desired $\beta$-glycoside was produced in 53\% yield, accompanying the $\alpha$-isomer (16\%). The solid-phase synthesis of 12 was performed in a similar strategy. In this study, we utilized a vortexing tube-mixer to gain more vigorous mixing in the manual step for introduction of $\mathbf{1 5}$ (2.6 equiv.). The reaction was run for $24 \mathrm{~h}$. The glycosylated heptacosapeptide thus synthesized on resin was cleaved with reagent K. HPLC and MS analyses indicated that there were few non-glycosylated peptides in the products. The fully benzylated glycopeptide (52\%), two monodebenzylated glycopeptides (31\%) and di-debenzylated glycopeptides $(5 \%)$ were the products. The isolated glycopeptides were combined and deprotected with 1M TMSOTf-TFA and thioanisole. This hard acid-soft nucleophile reaction was remarkably useful for the cleavage of benzyl ether in the acid-labile oligosaccharide. In this case, catalytic hydrogenation was useless due to the presence of a labile cystein residue. Finally, hydrolysis of the lactone in the carbohydrate portion and cleavage of the disulfide linkage derived by dimerization were accomplished by treatment with aq. $\mathrm{NaHCO}_{3}$ and dithiothreitol to afford $\mathbf{1 2}$ in $85 \%$ yield (21).

This strategy was also successful in the solid-phase synthesis of a glycopentapeptide carrying three consecutive sialyl$\mathrm{T}$ antigens. This study enables us to prepare an $\mathrm{N}$ - and side chainfully protected glycopeptide 20 by employing HMPB-BHA resin, a weak acid-labile resin, and HATU-HOAt-DIEA as the activators in NMP. The coupling reactions with trisaccharide building blocks 15 and 16 ( 1.5 equiv.) were run for $2 \mathrm{~h}$. Cleavage of the product from resin was facilitated with $1 \%$ TFA-1\% benzaldehyde in $\mathrm{CH}_{2} \mathrm{Cl}_{2}$ to prevent undesired debenzylidenation in the acidic mixture. Purification by gel-permeation chromatography afforded $\mathbf{2 0}$ in $81 \%$ overall yield. The full deprotection was also carried out by debenzylation with the above TMSOTf-thioanisole combination and then by lactone-hydrolysis with aq. $\mathrm{NaHCO}_{3}$ to exclusively give the glycopentapeptide representing glycophorin AM $\left(\mathrm{Ser}^{1}-\mathrm{Gly}^{5}\right)$ (22). The protected glycopeptide such as $\mathbf{2 0}$ would be a potent intermediate in the peptide-segment coupling reactions. (Fig. 3)

The core class 2 O-linked glycans are of particular interest, because it has been reported that the core 2 glycans express on leukosialin, the major surface glycoprotein of T-lymphocyte, when the cells are activated by anti-CD3 antibodies or interleukin-2. Appearance of the glycans is also associated with imunodeficient syndromes such as the Wiskott-Aldrich syndrome, leukemia, and AIDS. In 1999, we reported the first synthesis of the threonine-linked disialylated glycohexaose in a
触還元して 13 をヘンイコサペプチド樹脂から $26 \%$ の通算収率 で得た(20)。この14のカップリングにおける低収率の原因の一 つとして固液混合物の擋拌が不十分であることが考えられた。 次に、シアル酸とシステイン残基を含む天然 $\mathrm{B}$-鎖分子の合成を 行った。必要な 3 糖ビルディングブロック 15 は 2 糖トリクロ ロアセトイミダート 17 による 18 のグリコシル化を経て調製し た。望みの $\beta$-グリコシドは $53 \%$ の収率で得られ、 $\alpha$-異性体 $(16$ \%) も生成した。同様な戦法で 12 の固相合成を行った。この研 究では 15 (2.6 当量) を導入する手動工程でさらに激しくまぜる ためにボルテックス試験管ミキサーを利用した。反応は 24 時間 かけて行った。このようにして合成した糖へプタコサペプチド は reagent Kで切り出した。HPLC とマススペクトル分析は生成 物中には糖の入っていないペプチドがほとんど無いことを指し

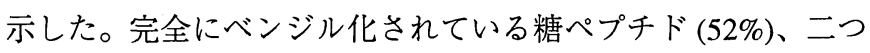
のモノ脱ベンジル体 $(31 \%)$ そしてジ脱ベンジル化糖ペプチド $(5$ \%)が生成物であった。単離した糖ぺプチドを合わせ、1 M TMSOTf-TFA およびチオアニソールを用いて脱保護した。この ハードな酸とソフト求核剤の反応は酸に不安定な糖鎖のベンジ ルエーテル切断にきわめて有効であった。この場合不安定なシ ステインがあるため接触還元は使えない。最後に重曹水とジチ オスレイトール処理で糖部分のラクトンの加水分解抢よび 2 量 化で生じたジスルフィド結合の開裂を行って 12 を $85 \%$ の収率 で得た(21)。

この合成戦略はシアリル T抗原を連続して持つ糖ペプチド の固相合成にも有効であった。この研究では弱酸で切れる樹脂 である HMPB-BHA 樹脂を使い、NMP 中で活性化剤 HATUHOAt-DIEA を用いてN と側鎖が完全に保護された糖ぺプチド 20 を合成した。3 糖ビルディングブロック 15 と 16 (1.5当量)を 用いるカップリングは 2 時間で行った。生成物の樹脂からの切 断は $1 \%$ TFA と $1 \%$ ベンズアルデヒドを含むジクロロメタン で行い、酸性の混合物中で起こる望ま脱ベンジリデン化を抑 えた。ゲル滤過クロマトグラフィーで精製し20を $81 \%$ の通算 収率で得た。完全脱保護は上記TMSOTf-チオアニソール混液に よる脱ベンジル化そして重曹水によるラクトンの加水分解で行 い、グリコホリン $\mathrm{AM}\left(\mathrm{Ser}^{1}-\mathrm{Gly}^{5}\right)$ に相当する糖ペンタペプチド とした(22)。20 のように保護された糖ぺプチドはペプチドのセ グメントカップリング反応の可能な中間体となるだろう(図 3)。

コアクラス 2 の O-結合型糖鎖は特に興味深い。T-リンパ球 の主要な表層糖タンパク質であるロイコシアリンが抗 CD3 抗体 やインターロイキン 2 で活性化されるとコア 2 糖鎖が発現する。 その糖鎖は Wiskott-Aldrich 症や白血病、AIDS などの免疫不全 症候群でも出現する。1999年われわれはトレオニンに結合した ジシアシル化 6 糖をベンジル保護体として初めて合成した。6 糖 21 の合成は収敛的合成法を念頭において 3 糖前駆体 22 と 23 と 


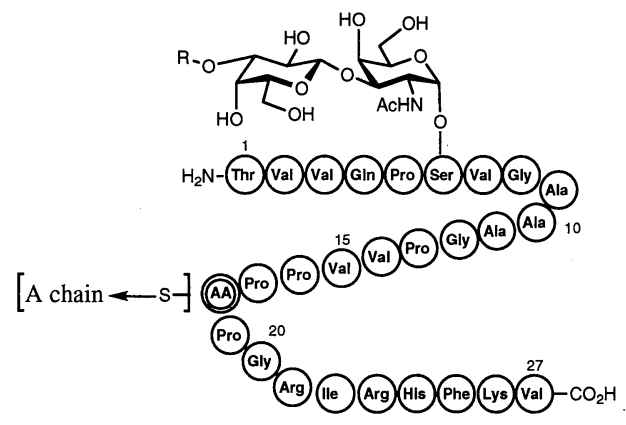

12: $R=$ Neu5Ac, $A A=$ Cys

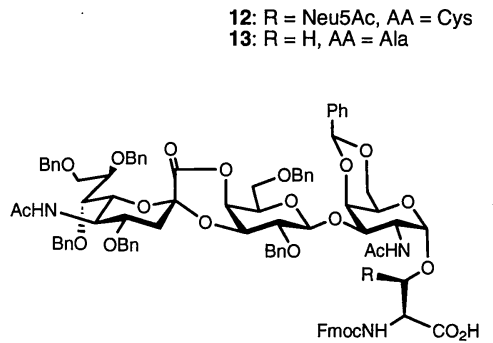

15: $\mathrm{R}=\mathrm{H}$
16: $\mathrm{R}=\mathrm{CH}_{3}$

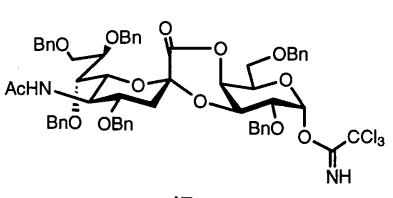

17

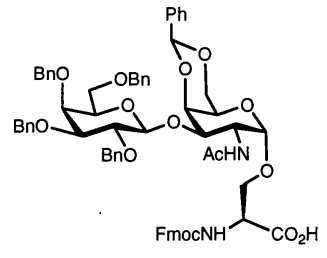

14
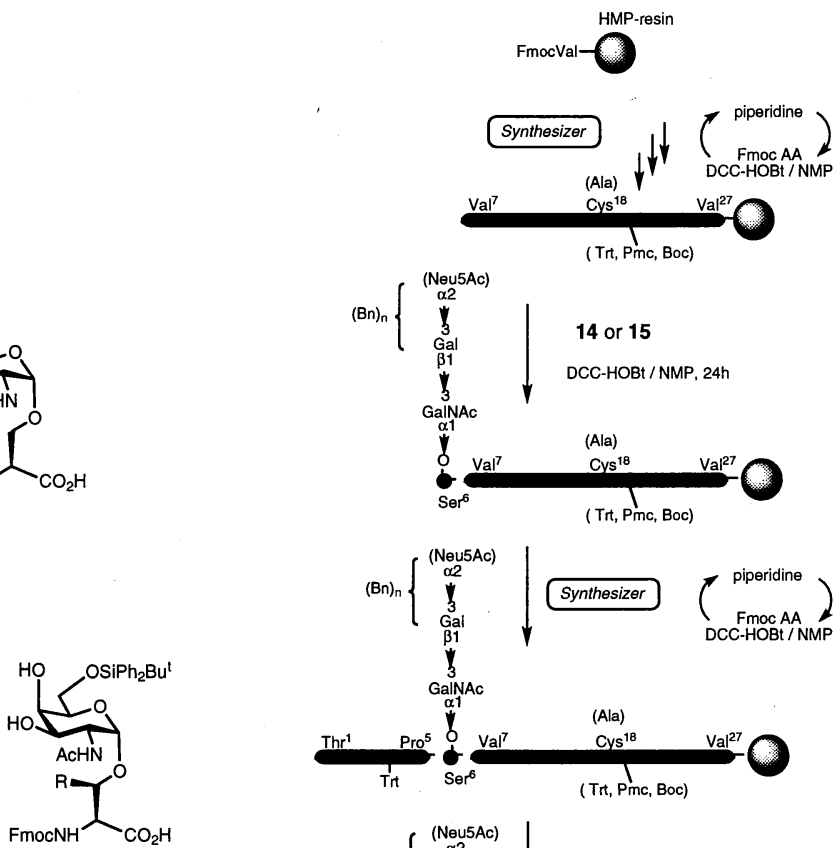

18: $\mathrm{R}=\mathrm{H}$

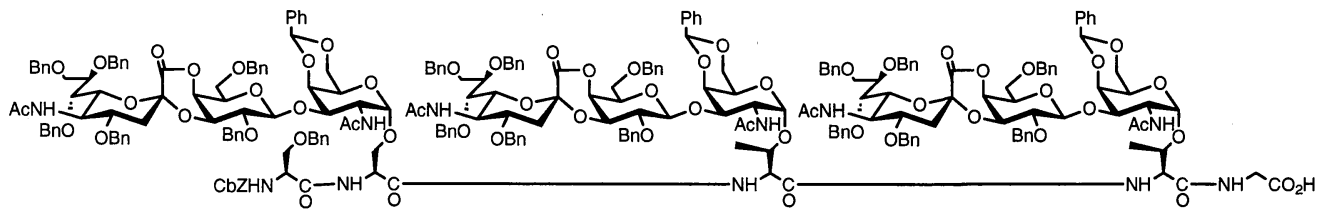

20

Fig. 3.

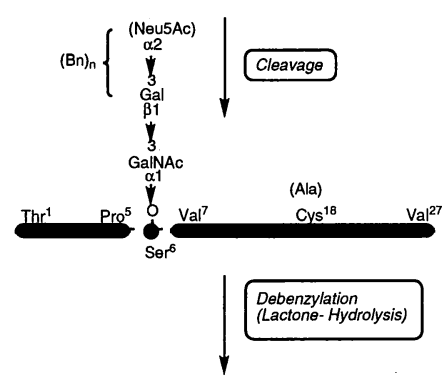

12,13 benzyl-protected form. The synthesis of the hexasaccharide $\mathbf{2 1}$ was designed to combine two trisaccharide precursors, $\mathbf{2 2}$ and 23, by considering the advantage of convergent synthesis. The trisaccharide $\mathbf{2 3}$ was readily obtained from the common precursor for 16. Another counterpart, the Neu5Ac-Gal-GlcNAc precursor, was synthesized by coupling of $\mathbf{1 7}$ and $\mathbf{2 4}$. The reaction was catalyzed by TMSOTf to afford a mixture of the isomeric products in $75 \%$ yield, but the $\beta$-selectivity was insufficient ( $\beta /$ $\alpha=2 / 1)$. The separated $\beta$-glycoside was converted into the trichloroacetimidate 22 and reacted with 23 by catalysis of TMSOTf. The glycosidation reaction gave a mixture of the desired $\beta$-glycoside and the $\alpha$-isomer $(\beta / \alpha=3 / 1)$. The azide groups were reductively acetylated with thioacetic acid and pyridine to afford the hexasaccharide $\mathbf{2 1}$ which would be a potent precursor for the core 2 building block used in the solid-phase synthesis of glycopeptides (23). However, the quantity of hexasaccharide 21 thus obtained was inadequate to use in further studies mainly due to the rather lengthy synthetic scheme and some difficulties in the stereocontrol for glycoside formation.

On the other hand, it has been known that the $\mathrm{N}$ phthaloylated glucosamine derivatives give the $\beta$-glycosides in high stereoselectivity. Syntheses of core 2 oligosaccharides with
を結合するようデザインした。 3 糖 $\mathbf{2 3}$ は $\mathbf{1 6}$ との共通前駆体か ら容易に得られる。もう一方すなわち Neu5Ac-Gal-GlcNAc 前駆 体は、17 と 24 のカップリングで合成される。その反応は TMSOTf によって触媒され $75 \%$ の収率で異性体混合物を与え たが、 $\beta$-選択性は不十分であった $(\beta / \alpha=2 / 1)$ 。分離した $\beta$-グリ コシドはトリクロロアセトイミダート 22 に変換し TMSOTf 触 媒で 23 と反応した。そのグリコシド化反応は求める $\beta$-グリコ シドとその $\alpha$-異性体の混合物を生じた $(\beta / \alpha=3 / 1)$ 。アジド基を チオ酶酸とピリジンで還元的にアセチル化して 6 糖 21 とした。 これは糖ぺプチド固相合成で用いるコア 2 型ビルディングブ ロックとして可能な前駆体である(23)。しかしながら、このよう にして得た 6 糖 21 の量はさらなる研究に展開するには不十分 であり、それは主に合成ステップが長すぎるのとグリコシド生 成時の立体化学の制御が困難な点に起因する。

ところで、N-フタロイル化されたグルコサミン誘導体は高 い選択性で $\beta$-グリコシドを与えることが知られている。この立 体制御基を用いるコア 2 糖鎖の合成は以前から他のグループに 
this stereocontrolling group have previously been reported by other groups (24-26). The N-phthaloyl group should be removed under a basic condition and displaced by an acetyl group before the oligosaccharide being attached to the serine and threonine derivatives. Paulsen et al. synthesized a serine-linked tetrasaccharide through preparation of the oligosaccharide part with an $\mathrm{N}$-phthaloyl lactosamine derivative. The reaction between the acetylated tetrasaccharyl thioglycoside and Cbz-Ser-OBn was promoted with DMTST to give the coupling products as an anomeric mixture $(\alpha / \beta=2 / 1)$. Recently, we have synthesized the corresponding core 2 tetrasaccharide-serine that was benzylated and suitably protected for Fmoc peptide chemistry. The synthesis was designed so as to condense disaccharide donor 25 and acceptor 26. The TMSOTf-promoted glycosylation exclusively gave the desired $\beta$-glycoside 27 , which was converted into glycosyl fluoride $\mathbf{2 8}$ in five steps including dephthaloylation The crucial glycosylation of Fmoc-Ser-OAll with 28 , however, resulted in poor stereoselectivity $(\alpha / \beta=1 / 1)$ to afford the $\alpha$-glycoside in moderate yield. The azide group was transformed into acetamide and the allyl ester was cleaved by $\operatorname{Pd}(0)$-catalyzed reaction to furnish the core 2 tetrasaccharide building block 29 (27).

The frustration caused by the incomplete stereocontrol in the syntheses of hexasaccharide and tetrasaccharide prompted us to search for a novel approach to the synthetic core 2 glycopeptides.

In addition to the $\mathrm{N}$-phthaloyl group, a variety of $\mathrm{N}$-protecting groups for glucosamine that permitted $\beta$-selective glycosylation was reported. The $\mathrm{N}$-trichloroacetyl group seemed to meet our requirements because the group is converted into an $\mathrm{N}$-acetyl group without any base treatment. Disaccharide 30 was prepared starting from 24 and 2,3,4,6-tetra-O-acetyl- $\alpha$-Dgalactopyranosyl bromide. Glycosylation of $\mathbf{3 1}$ and $\mathbf{3 2}$ with glycosyl fluoride 30 was readily promoted by $\mathrm{Cp}_{2} \mathrm{ZrCl}_{2}-\mathrm{AgClO}_{4}$ to exclusively give the $\beta$-glycosides in $70-72 \%$ yield. Both the trichloroacetamide and azide were converted into acetamido groups by reduction with $\mathrm{Zn}-\mathrm{AcOH}$ and subsequent acetylation. De-allylation afforded $\mathbf{3 3}$ and $\mathbf{3 4}$. The usefulness of building block 34 was demonstrated by the solid-phase synthesis of a segment of human leukosialin ( $\left.\mathrm{Pro}^{215}-\mathrm{Val}^{224}\right)$. A decapeptide carrying the core 2 tetrasaccharide at $\mathrm{Thr}^{216}$ was synthesized as a prototype of glycopeptide. The solid-phase synthesis was performed on the Sieber amide resin that can release synthetic peptide as the $\mathrm{C}$-terminal amide under mildly acidic conditions. According to the Fmoc protocol with the condensing reagents of DCC-HOBt-DIEA, the eight amino acids were assembled by a manual operation with a vortical mixing machine. The resulting octapeptide-resin was reacted with $\mathbf{3 4}$ (2 equiv.) by activation with HATU-DIEA in NMP overnight. Then N-terminal proline was condensed to complete the target glycodecapeptide, which was then cleaved from the resin with reagent $\mathrm{K}$. The syn-
よって報告されてきている(24-26)。その $\mathrm{N}$-フタロイル基はセリ ンやトレオニンと結合する前に塩基性条件で除去されアセチル 基で置き換えなければならない。Paulsen らは N-フタロイルラ クトサミンを使って糖鎖部分を調製しセリンと結合した 4 糖を 合成している。アセチル化された 4 糖チオグリコシドと Cbz-SerOBn との反応は DMTST によって促進されカップリング生成物 をアノマー混合物として与えた $(\alpha / \beta=2 / 1)$ 。最近われわれは相 当するコア 2 型 4 糖セリンをベンジル化され、Fmoc ペプチド 合成に適した保護がなされたものとして合成した。その合成は 2 糖供与体 25 と受容体 26 とを縮合するようデザインした。そ の TMSOTf によるグリコシド化はもっぱら望みの $\beta$-グリコシド 27 をあたえたが、それはひきつづき脱フタロイル化を含む $5 工$ 程で糖フルオリド 28 に変換した。問題の 28 による Fmoc-SerOAll のグリコシル化はしかしながら立体選択性に乏しく $(\alpha / \beta=$ 1/1) $\alpha$-グリコシドは中程度の收率でしか得られなかった。アジ ド基のアセトアミドへの变換と $\operatorname{Pd}(0)$ 触媒反応によるアリルエ ステルの切断はコア 2 型 4 糖ビルディングブロック 29 を生成 した(27)。

この 6 糖と 4 糖合成における不完全な立体制御への欲求不 満からコア 2 型糖ぺプチド合成の新しい方法を探索することと なった。

N-フタロイル基に加え $\beta$-選択的なグリコシル化を可能とす るグルコサミンのいろいろな $\mathrm{N}$-保護基が報告されている。 $\mathrm{N}$-卜 リクロロアセチル基は塩基処理無しに $\mathrm{N}$-アセチル基に変換でき るため、われわれの要求に合致するものと思われた。24 とテト ラアセチルガラクトシルブロミドとから出発して 2 糖 $\mathbf{3 0}$ を調 製した。グリコシルフルオリド $\mathbf{3 0}$ を用いた $\mathbf{3 1}$ と $\mathbf{3 2}$ のグリコ シル化反応は $\mathrm{Cp}_{2} \mathrm{ZrCl}_{2}-\mathrm{AgClO}_{4}$ で容易に促進され、70 72\%の 収率でもっぱら $\beta$-グリコシドを与えた。トリクロロアセトアミ ドとアジドは共に亜鉛-酶酸による還元とそれにつづくアセチル 化によってアセトアミド基へと変換された。ビルディングブ ロック 34 が有用であることはヒトロイコシアリン $\left(\mathrm{Pro}^{215}-\mathrm{Val}^{224}\right)$ のセグメントの固相合成で示された。Thr ${ }^{216}$ にコア 2 型 4 糖を 結合するデカペプチドを糖ペプチドのプロトタイプとして合成 した。固相合成はC-末端がアミドの合成ぺプチドを弱酸で切り 出すSieber アミド樹脂上で行った。DCC-HOBt-DIEAを縮合剂 として Fmoc 法に従い、渦巻き型項は攪拌機をもちいて手動で 8 アミノ酸をつないだ。生成したオクタペプチド樹脂を NMP 中 HATU-DIEA によって活性化して 34 ( 2 当量) と終夜反応した。 さらにN-末端のプロリンを縮合して標的糖ペプチドを完成し、

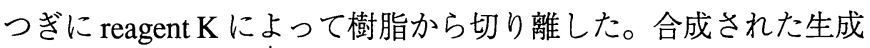


thesized product was fully deprotected under the conditions of low-acidity trifluoromethanesulfonic acid (10\% TfOH, $30 \%$ $\mathrm{Me}_{2} \mathrm{~S}, 8 \%$ m-cresol, $2 \%$ 1,2-ethanedithiol, 50\% TFA) at $-15^{\circ} \mathrm{C}$ for $2 \mathrm{~h}$, precipitated in ether, and chromatographed with a reversed-phase column. The procedure efficiently provided $\mathbf{3 5}$ in $27 \%$ overall yield with minimal losses on the oligosaccharide structure (28). Recently, we were able to transform the tetrasaccharide of $\mathbf{3 5}$ into the disialohexasaccharide by enzymatic reactions with commercial enzymes. Incubation of $\mathbf{3 5}$ with CMPsialic acid, recombinant rat $\beta$-Gal- $\beta 1,3 / 4-G l c N A c-\alpha 2,3-$ sialyltransferase and $\beta$-Gal- $\beta 1,3-$ GalNAc- $\alpha 2,3$-sialyltransferase at $\mathrm{pH} 6.8$ for $12 \mathrm{~h}$ exclusively gave disialylated $\mathbf{3 6}$ (29). (Fig. 4) (Fig. 5)

Solid-phase glycopeptide synthesis with the building blocks carrying non-protected oligosaccharides has been an attractive method, because the potential risks of side-reactions generated in deprotection under basic or acidic conditions might be avoided. Some preceding studies have been presented by other groups. We also examined the possibility of this approach in combination with the on-resin fragment condensation strategy. The C-terminal hexadecapeptide of $\beta$ hCG $\left(\operatorname{Ser}^{130}-\mathrm{Gln}^{145}\right)$ that involved two serine-linked Gal-GalNAc at $\operatorname{Ser}^{132}$ and $\operatorname{Ser}^{138}$ was
物は “low-acidity trifluoromethanesulfonic acid (10\% TfOH, 30\% $\mathrm{Me}_{2} \mathrm{~S}, 8 \%$ m-cresol, 2\% 1,2-ethanedithiol, 50\% TFA)”の条件下一 $15^{\circ} \mathrm{C} 、 2$ 時間で完全脱保護し、エーテル中に沈澱させ、さらに 逆相カラムを用いたクロマトグラフィーを行った。このやり方 で糖鎖構造の欠損もほとんど無しに 35 が $27 \%$ の累計収率で得 られた(28)。最近われわれは 35 の 4 糖を市販の䤉素を用いた酵 素反応によってジシアロ 6 糖へと変換することができた。35を CMP-シアル酸、リコンビナントのラット $\beta-G a l-\beta 1,3 / 4-G l c N A c-$ $\alpha 2,3-$ シアル酸転移酵素および $\beta$-Gal- $\beta 1,3-G a l N A c-\alpha 2,3-$ シアル酸 転移䣼素とともに $\mathrm{pH} 6.8$ で 12 時間インキュベートすると、もっ ぱらジシアリル化された36が生成した(29) (図 4) (図 5)。

脱保護時の塩基や酸条件により生じる副反応のリスクを回 避できるため、糖鎖無保護のビルディングブロックを使っての 固相合成も興味深い方法である。他のグループによりいくつか の先行する研究が示されている。われわれもその可能性を樹脂 上でのフラグメント縮合戦略と組み合わせて探ることとした。 二つの Gal-GalNAc を $\operatorname{Ser}^{132}$ と $\operatorname{Ser}^{138}$ に結合した $\beta$ hCG $\left(\operatorname{Ser}^{130}\right.$ $\left.\mathrm{Gln}^{145}\right)$ の C-末端へキサデカペプチドを合成した。その糖ぺプチ ドは逆合成的に二つのセグメントに分け、そのいずれもを Sieber
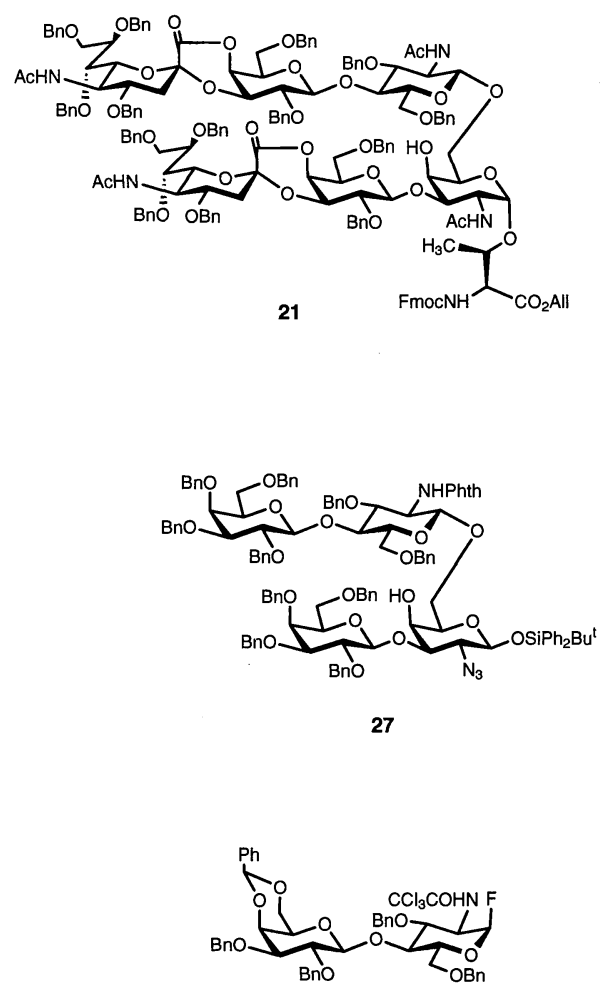

30
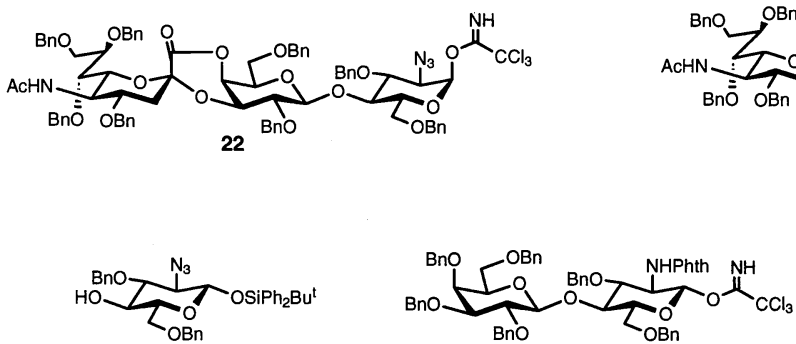

25
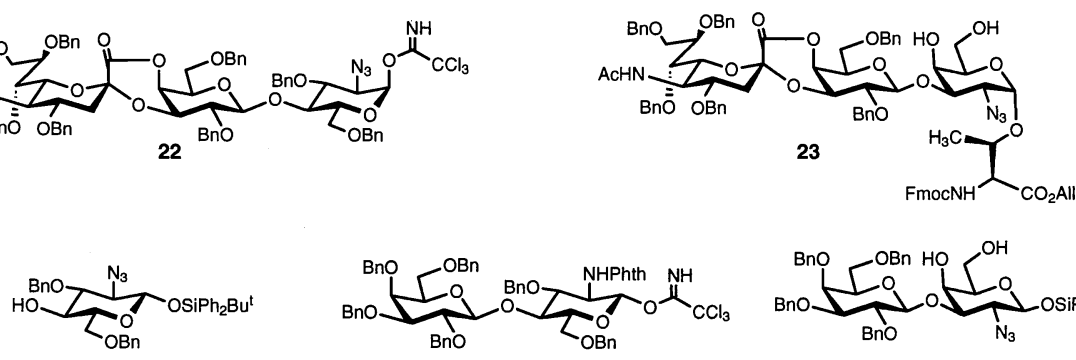

24

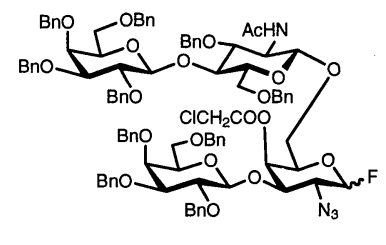

28

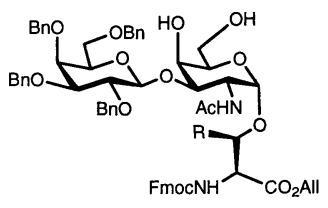

31: $\mathrm{R}=\mathrm{H}$

Fig. 4
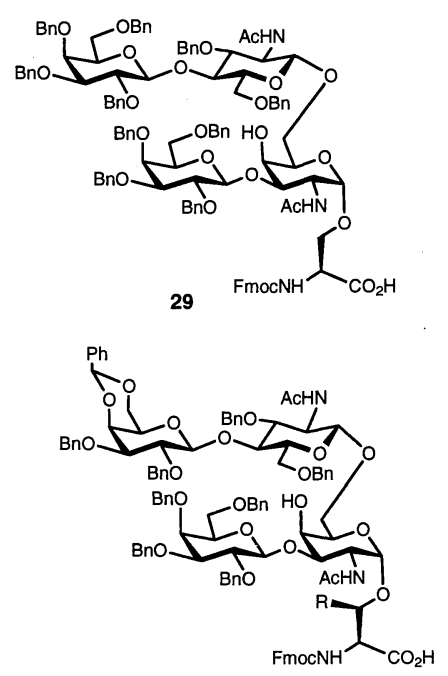

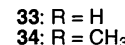




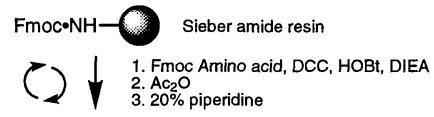

$\mathrm{H} \cdot \operatorname{Thr}\left(\mathrm{Bu}^{t}\right)-\operatorname{Ser}\left(\mathrm{Bu}^{t}\right)-\operatorname{Thr}\left(\mathrm{Bu}^{\mathrm{t}}\right)-\mathrm{Asn}(\mathrm{Trt})-\mathrm{Ala}-\operatorname{Ser}\left(\mathrm{Bu}^{t}\right)-\operatorname{Thr}\left(\mathrm{Bu}^{t}\right)-\mathrm{Val}-\mathrm{NH}-$

$$
\downarrow \begin{aligned}
& \text { 1.34, HATU, DIEA } \\
& \text { 2. } 20 \% \text { piperidine }
\end{aligned}
$$

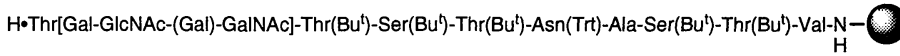

$$
\downarrow \text { 1. Fmoc•Pro, DCC, HOBt, DIEA }
$$

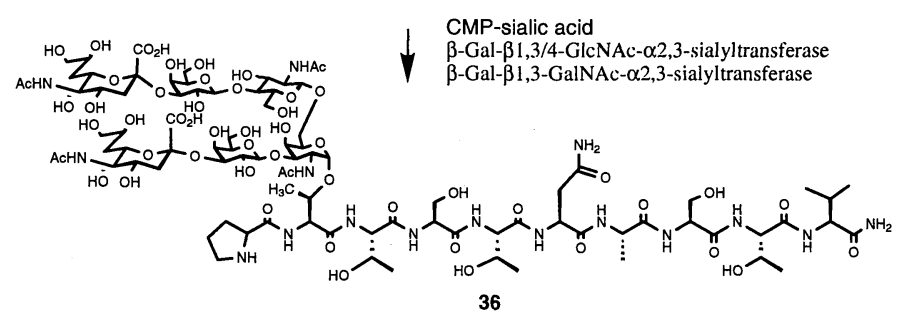

Fmoc•Pro-Thr[Gal-GlcNAc-(Gal)-GalNAc]-Thr(But $)-\operatorname{Ser}\left(\mathrm{Bu}^{t}\right)-\operatorname{Thr}\left(\mathrm{Bu}^{t}\right)-\operatorname{Asn}(\operatorname{Trt})-\operatorname{Ala}-\operatorname{Ser}\left(\mathrm{Bu}^{t}\right)-\operatorname{Thr}\left(\mathrm{Bu}^{t}\right)-\operatorname{Val}-\mathrm{N}$

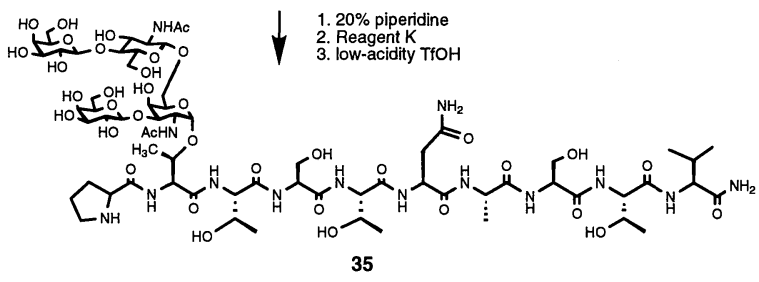

Fig. 5.

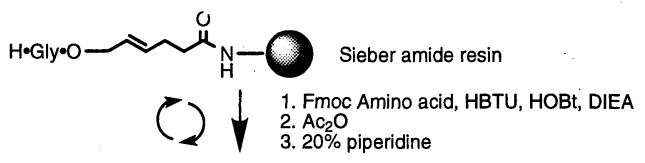

$\operatorname{Arg}(\mathrm{Pmc}) \cdot \mathrm{Leu} \cdot \mathrm{Pro} \cdot \mathrm{Gly} \cdot \mathrm{O} \sim \mathrm{N}_{\mathrm{H}}-\mathrm{O}$

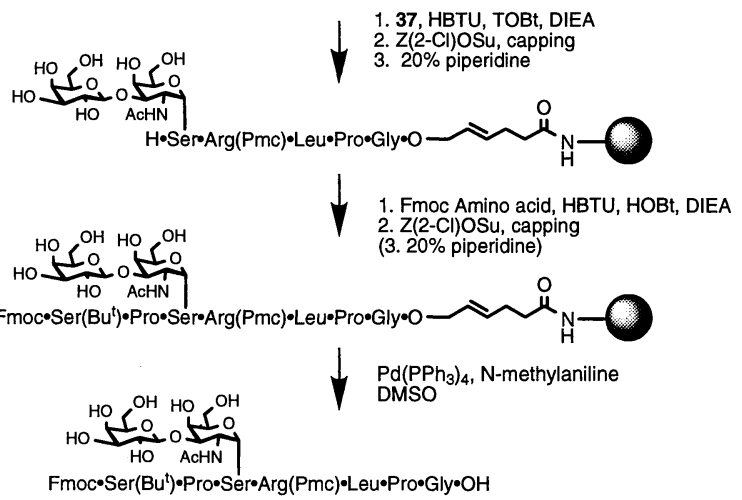

38

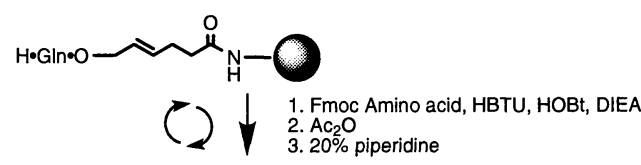

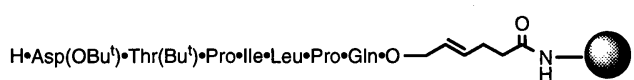

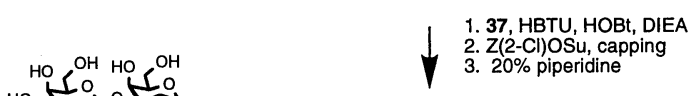

HO

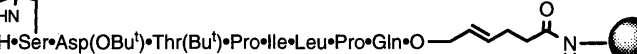

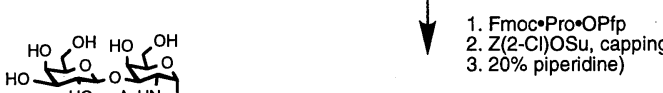
\begin{tabular}{ll}
$\mathrm{HO} \mathrm{C}_{0} \mathrm{~S}_{\mathrm{O}}$ & $3.20 \%$ piperidine) \\
\hline
\end{tabular}

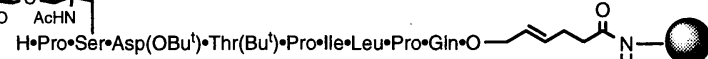

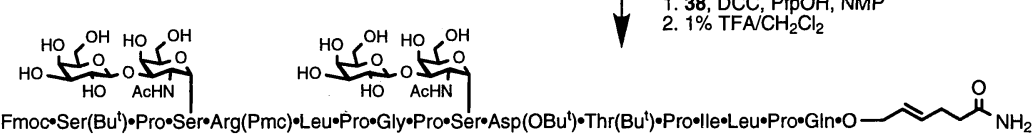

39

Fig. 6.

synthesized. The glycopeptide was retrosynthetically disconnected into two segments, both of which were prepared on the allyl linker attached to the Sieber amide resin. The allyl linker had previously been developed in this group (vide infra) in analogy with Kunz's Hycram and Hycron linkers that can release the synthesized glycopeptides from resin by catalysis of $\operatorname{Pd}(0)$ (30-33). The unmasked glycoserine unit 37 was prepared by deprotection of $\mathbf{1 4}$ with TMSBr-TFA. Fmoc glycine was loaded to the Sieber amide resin interposing the allyl linker. The tet-
アミド樹脂につけたアリルリンカー上で合成した。アリルリン カーは Kunz の Hycram と Hycron リンカーの類似体としてわれ われのグループ (下記) で以前に開発したものであり、 $\operatorname{Pd}(0)$ 触 媒で合成糖ぺプチドを樹脂から切り出すことができる(30-33)。 無保護の糖セリンユニット $\mathbf{3 7}$ は $\mathbf{1 4}$ を TMSBr-TFA で脱保護す ることで調製される。アリルリンカーを間に挟んで Fmoc グリ シンを Sieberアミド樹脂上に結合した。自動の FastMoc 法でテ トラペプチドを並べ 37 (1.2 当量)は HBTU-HOBt-DIEA (1.1 当 
rapeptide was assembled by an automated FastMoc protocol and 37 (1.2 equiv.) was manually condensed by activation with HBTU-HOBt-DIEA (1.1 equiv.). The reaction mixture was stirred for $24 \mathrm{~h}$ using a vortex mixer. Incorporation of proline, and then serine, was performed with their pentafluorophenyl esters preventing the undesired $\mathrm{O}$-acylation. $\mathrm{Pd}(0)$-catalyzed cleavage of the allyl ester linkage afforded $\mathbf{3 8}$ in $51 \%$ overall yield, which could be used as a segment for on-resin coupling. Another segment $\left(\mathrm{Pro}^{137}-\mathrm{Gln}^{145}\right)$ was analogously synthesized on the resin, and the crucial coupling reaction was realized by mixing the resin and $\mathbf{3 8}$ ( 2 equiv.) for 7 days at room temperature in the presence of DCC-PfpOH. The product detached from the resin with a weak acid was chromatographed by HPLC to give 39 in 30\% overall yield, and no unreacted C-terminal segment was detected in the chromatogram. This result strongly assisted the potential usefulness of unmasked oligosaccharide in the solid-phase glycopeptide synthesis (34). (Fig. 6)

\section{Synthesis of $\mathbf{N}$-glycopeptides}

The importance of N-linked oligosaccharides is often noted relating to the functional conformation of glycoprotein. $\mathrm{N}$-linked oligosaccharides are also known to participate in the folding of protein in the early stage of the biosynthesis. A number of studies have been made on the synthesis of N-linked oligosaccharides in order to solve the difficult problems incurred in the stereocontrol of the glycoside linkages present in the complex structures (35). The incorporation of the synthesized Nlinked oligosaccharides into the glycopeptide structures has been investigated in this group. In 1995 the core pentasaccharide $\mathbf{4 0}$ of $\mathrm{N}$-glycan was synthesized in a benzyl-protected form and converted into a glycotripeptide $\mathbf{4 1}\left(\alpha \mathrm{hCG}\right.$ : $\left.\mathrm{Asn}^{78}-\mathrm{Thr}^{80}\right)$ through coupling with dipeptidyl amine by activation with WSC-HOBt, $\mathrm{N}$-deprotection with morpholine, and then hydrogenolysis (36). The usefulness of $\mathbf{4 0}$ as the building block for the solid-phase synthesis was demonstrated in the synthesis of a glycan-shortened segment of CD 52, a GPI-anchored glycoprotein. The solidphase synthesis was started with the commercial Fmoc serinepreloaded Wang resin. In a similar manner to that described for glycopeptide12, the nonapeptide was assembled according to the automated synthesizer's protocol. Reaction of $\mathbf{4 0}$ and the peptide on the resin was performed with the same activating agents by vortex mixing overnight. Two more amino acids were condensed and the resulting glycopeptide was released from the resin with reagent $\mathrm{K}$. The product was purified by gel-permeation chromatography and finally deprotected by hydrogenolysis to afford $\mathbf{4 1}$ in good yield (37). (Fig. 7)

Emmprin (extracellular matrix metalloproteinase inducer), a tumor cell-derived $-58 \mathrm{kDa}$ glycoprotein, stimulates fibroblasts to express several matrix metalloproteinases (MMPs) in the fibroblasts and functions in a crucial step of tumor cell invasion and metastasis. The extracellular Ig domain I (Gly ${ }^{34}$ -
量)で活性化しボルテックスミキサーを用いて 24 時間手動によ る縮合をした。望まぬ O-アシル化を避けるためプロリンとつづ くセリンの導入はペンタフルオロフェニルエステルを用いて 行った。 $\operatorname{Pd}(0)$ 触媒によるアリルエステル結合の切断で 38 が 51 $\%$ の通算収率で得られ、それは樹脂上でのカップリングのため のセグメントとして用いることができた。もうひとつのセグメ ント $\left(\mathrm{Pro}^{137}-\mathrm{Gln}^{145}\right)$ も同様に樹脂上で合成された。課題のカップ リング反応はその樹脂と 38 ( 2 当量)を DCC-PfpOH 存在下に 7 日間室温でかき混ぜることで達成された。弱い酸で樹脂から切 り離された生成物は HPLCによるクロマトグラフィーで 39 を $30 \%$ の通算収率で与え、未反応の C-末端側セグメントはクロ マトグラム中には見いだされなかった。この結果は糖ぺプチド の固相合成における無保護糖鎖の有用性を強く支持するもので ある(34) (図 6)。

\section{N-糖ペプチドの合成}

$\mathrm{N}$-結合型糖鎖の重要性はしばしば糖タンパク質の機能性コ ンホメーションと関連づけて注目される。N-結合型糖鎖はまた 生合成の初期段階でのタンパク質のフォールディングに関与し ていることが知られている。その複雑な構造中のグリコシド結 合の立体制御の困難な問題を解決するため、N-結合型糖鎖の合 成については多くの研究がある(35)。われわれのグループでも合 成 $\mathrm{N}$-結合型糖鎖の糖ペプチド構造への導入を研究してきた。 1995 年 $\mathrm{N}$-結合型糖鎖コアの 5 糖 40 をベンジル保護型で合成し、 WSC-HOBt による活性化でのジペプチドアミンとのカップリン グ、モルホリンによる N-脱保護、そして加水素分解を経て糖卜 リペプチド $41\left(\alpha \mathrm{hCG}: \mathrm{Asn}^{78}-\mathrm{Thr}^{80}\right)$ に変換した(36)。固相合成用 ビルディングブロックとしての $\mathbf{4 0}$ の有用性は GPI アンカー型 糖タンパク質である CD 52 の糖鎖部を短くしたセグメントの合 成によっても示された。その固相合成は市販の Fmoc セリンを 担持した Wang 樹脂から始めた。糖ぺプチド 12 について述べ たのと同様に、ナノペプチドを自動合成装置の方法でつない だ。40のそのペプチドと樹脂上でのの反応は同じ縮合剤を使っ て終夜ボルテックスミキサーで行った。もう二つのアミノ酸を 縮合し生成した糖ペプチドを reagent K で樹脂から切り出した。 生成物はゲル濾過で精製した後、最後に加水素分解して $\mathbf{4 1}$ が好 収率で得られた(37) (図 7)。

エムプリン (extracellular matrix metalloproteinase inducer) は 腫瘍細胞由来の $58 \mathrm{kDa}$ の糖タンパク質であり繊維芽細胞を刺 激していくつかのマトリックスメタロプロテアーゼ (MMPs)を 発現させ腫瘍細胞の浸潤や転移の重要なステップに機能する。 

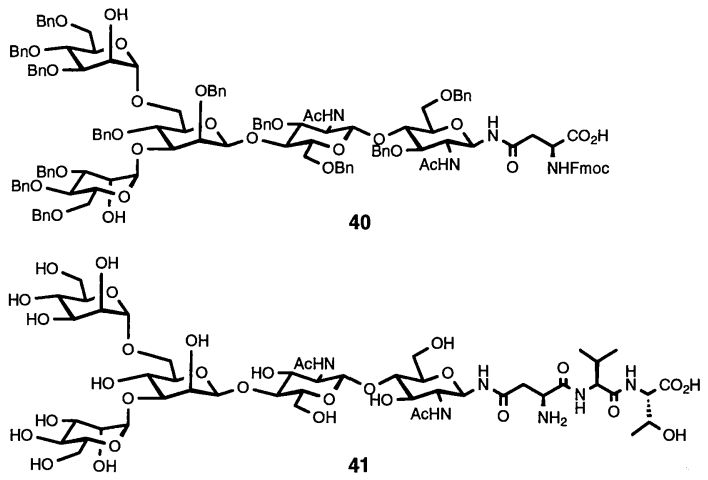

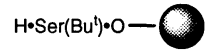

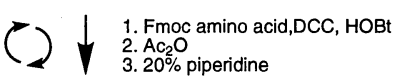

$H \cdot A \operatorname{sp}\left(B u^{t}\right) \cdot \operatorname{Thr}\left(B^{t}\right) \cdot \operatorname{Ser}\left(B u^{t}\right) \cdot G \ln (\operatorname{Trt}) \cdot \operatorname{Thr}\left(B u^{t}\right) \cdot \operatorname{Ser}\left(B u^{t}\right) \cdot \operatorname{Ser}\left(B u^{t}\right) \cdot \operatorname{Pro} \cdot \operatorname{Ser}\left(B u^{t}\right) \cdot 0$

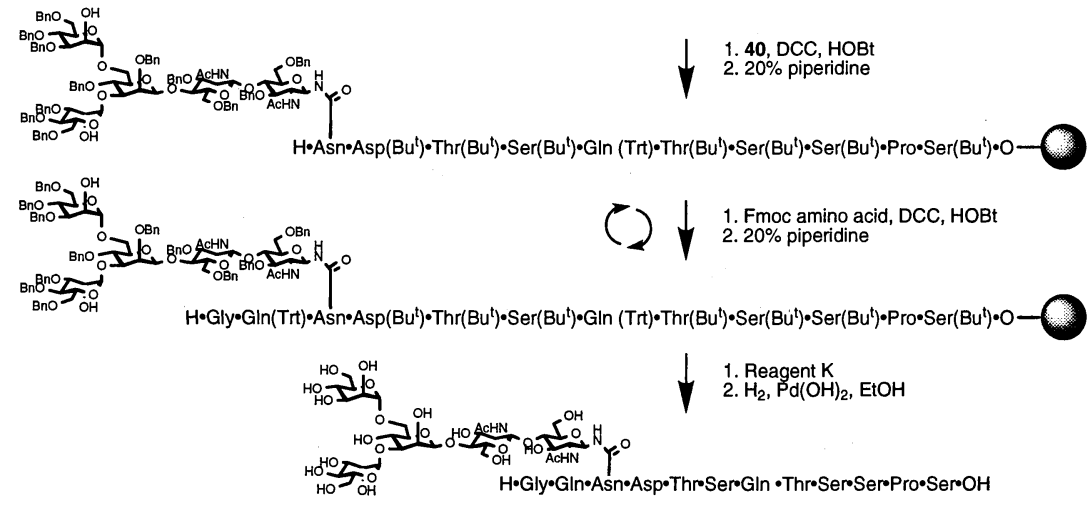

Fig. 7.
$\mathrm{Met}^{94}$ ) of the glycoprotein that involves an N-linked oligosaccharide at $\mathrm{Asn}^{44}$ is supposed to be the functional site. We planned to synthesize this glycohenhexacontapeptide 42 utilizing the thioester-mediated segment coupling method (38). Two segments were designed so as to couple the segments at Gly ${ }^{58}-\mathrm{Gly}^{59}$ with no concern about the stereoisomerism. A segment $\left(\mathrm{Gly}^{34}-\mathrm{Gly}^{58}\right)$ was prepared on the $\mathrm{HO}-\mathrm{CH}_{2}$-Pam resin with the thioester linker based on the Boc method. An $\mathrm{N}^{4}$-chitobiosyl asparagine 44 was employed as the prototype of $\mathrm{N}$-oligosaccharide building block and manually introduced by activation with DCC-HOBt. Cleavage of the glycopeptide thioester was performed with either $\mathrm{HF}$ or $1 \mathrm{M}$ TfOH-TFA to give the desired glycopeptide in $12-14 \%$ yield. At the same time GlcNAc-truncated peptide was also produced in 6-7\% yield. Both products were $\mathrm{N}$-protected with BocOSu to 45 and 46, which were used for the segment coupling reactions. The C-terminal segment $\left(\mathrm{Gly}^{59}-\mathrm{Met}^{94}\right) 47$ was prepared in $8.9 \%$ overall yield on the Rink amide MBHA resin using the Fmoc method. The coupling of 45 and 47 was promoted with AgCl-HOOBt-DIEA in DMSO and completed within $4 \mathrm{~h}$. All the protecting groups were removed by treatment with TFA and then with $\mathrm{AgNO}_{3}$-DIEA. The crude glycopeptide was purified by HPLC to give a linear glycopeptide (77\% yield), which was finally air-oxidized in aqueous DMSO with $1 \%$ $\mathrm{NH}_{4} \mathrm{OAc}$ overnight to produce $\mathbf{4 2}$ in $50 \%$ yield. The GlcNAclinked peptide 46 was also transformed into the corresponding glycohenhexacontapeptide (39). In a bioassay with these synthetic samples, it was proven that the chitobiose-linked glycopeptide presented remarkable MMP 2 (matrix metalloproteinase 2)-inducing activity. In contrast, little activity was observed for the non-glycosylated peptide. It is particularly surprising that the presence of such a small disaccharide on the peptide can control the bioactivity in view of the fact that the native emmprin
その細胞外イムノグロブリン様ドメイン I $\left(\mathrm{Gly}^{34}-\mathrm{Met}^{94}\right)$ には $\mathrm{Asn}^{44}$ にN-結合型糖鎖が結合しておりその機能性部位であると思われ ている。われわれはこの糖へンヘキサコンタペプチド 42 をチオ エステルを使ったセグメントカップリング法 (38) で合成するこ とを計画した。立体異性に関する不安の無いGly ${ }^{58}-G l y{ }^{59}$ 間で結 合すべく二つのセグメントをデザインした。一つのセグメント $\left(\right.$ Gly $\left.^{34}-G l{ }^{58}\right)$ は Boc 法によるチオエステルリンカーを利用して $\mathrm{HO}-\mathrm{CH}_{2}-\mathrm{Pam}$ 樹脂上で調製した。キトビオース結合のアスパラ ギン 44 を N-結合型糖鎖のひな型として使い、DCC-HOBt を活 性化剂として導入した。糖ぺプチドチオエステルの切り出しに はフッ化水素または $1 \mathrm{M}$ TfOH-TFA を用い、望みの糖ぺプチド が 12〜14\%の収率で得られた。同時に GlcNAc が切れた糖ぺ プチドが 6〜7\%生成した。両方の生成物共にBocOSu を用い て N-保護をし 45 および 46 とし、セグメントカップリング反 応に用いた。C-末端側セグメント $\left(\mathrm{Gly}^{59}-\mathrm{Met}^{94}\right) 47$ は Rink アミド MBHA 樹脂上で Fmoc 法によって通算収率 $8.9 \%$ で調製した。

45 と 47 のカップリングは DMSO 中でAgCl-HOOBt-DIEA によっ て促進され 4 時間以内に完結した。全ての保護基は TFA つづ いて $\mathrm{AgNO}_{3}$-DIEA 処理によって除去した。粗生成物を HPLCで 精製し、直鎖の糖ペプチド (収率 $77 \%$ )を得た。最後に $1 \%$ $\mathrm{NH}_{4} \mathrm{OAc}$ を含む含水 DMSO 中で終夜空気酸化することで $50 \%$ の収率で 42 が生成した。GlcNAc が結合した 46 もまた相当す る糖ヘンヘキサコンタペプチドに変換した(39)。これら合成サン プルのバイオアッセイではキトビオースが結合した糖ペプチド が顕著な MMP 2 (matrix metalloproteinase 2) 誘導活性を示した。 それに比べ糖の付いていないぺプチドではほとんど活性が観測 されなかった。天然のエムプリンは高度にグリコシル化されて 
is highly glycosylated. Notably, it has been reported that both acetamido groups on the chitobiose are critical to determining the $\beta$ turn structure at the Asn residue in the peptide (40). In order to discuss the relationship between conformation and activity of the Ig domain of emmprin, further experimental evidence would be necessary.

More recently, we have accomplished synthesis of the pentasaccharide-linked Ig domain fully based on the Fomc solidphase protocol. The glycosylated segment $\mathbf{4 8}$ was prepared on the Rink amide MBHA resin employing a special $\mathrm{N}$-deprotection agent (25\% 1-methylpyrrolidine- $2 \%$ hexamethylene imine- $2 \%$ HOBt in NMP-DMSO) (41). In the first attempt to prepare the tetradecapeptide $\left(\mathrm{Asp}^{45}-\mathrm{Gly}^{58}\right)$, we were confronted with low productivity of the desired peptide. The major byproduct ( 40\%) was the $\mathrm{C}$-terminally dipeptide-lacking thioester that might be produced after elimination as a diketopiperazine in the second de-Fmoc step. This cumbersomeness was prevented by taking advantage of the recently reported procedure involving a com-
いるのに、このように小さな 2 糖の存在が生物活性を制御でき るということは非常な驚きであった。キトビオース上の二つの アセトアミド基がペプチドのアスパラギン残基での $\beta$ ターン構 造を決めるのに重要に㗢くという注目すべき報告がなされてい る(40)。エムプリンの Ig ドメインのコンホメーションと活性と の関係を議論するにはさらなる実験事実を重ねる必要がある。 ごく最近われわれは 5 糖が結合した Igドメインの合成を Fomc 固相法のみを用いて達成した。糖の付加したセグメント 48 を特 別の N-脱保護試薬 (25\% 1-methylpyrrolidine-2\% hexamethylene imine-2 \% HOBt in NMP-DMSO)を用いて Rink アミドMBHA 樹 脂上で合成した(41)。テトラデカペプチド $\left(\mathrm{Asp}^{45}\right.$-Gly $\left.{ }^{58}\right)$ を調製す る最初の試みでは望みのペプチドが低収量でしか得られなかっ た。主な副生成物 ( 40\%) はC-末端のジペプチドが欠損したチ オエステルであり、それは 2 番めの脱 Fmoc 工程でジケトピペ ラジンを形成して脱離が起った後で生成したものと思われた。

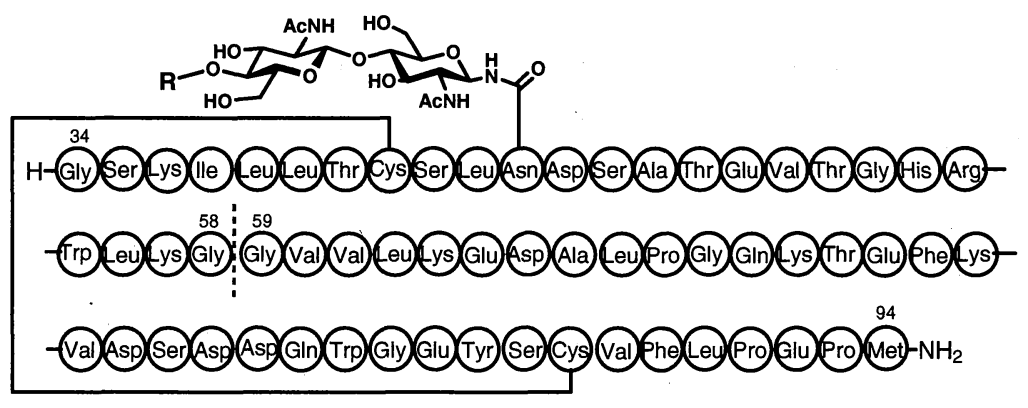

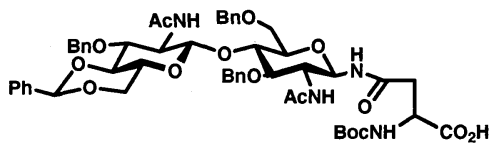

44

42: $\mathrm{R}=\mathrm{H}$

43: $R=\alpha-D-M a n-(1 \rightarrow 6)-[\alpha-D-M a n-(1 \rightarrow 3)]-\alpha-D-M a n-(1 \rightarrow$

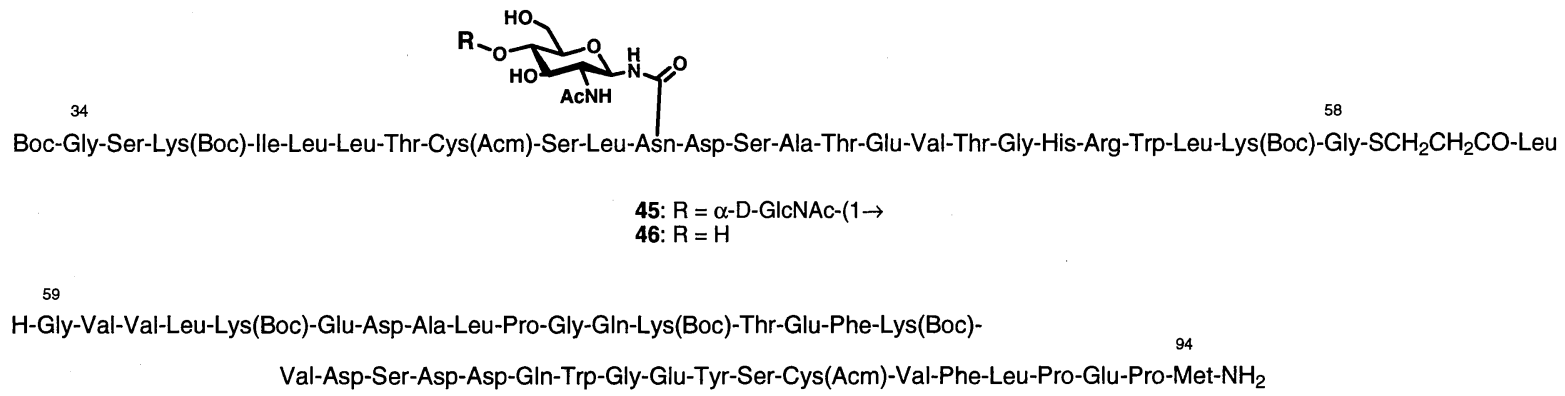

47

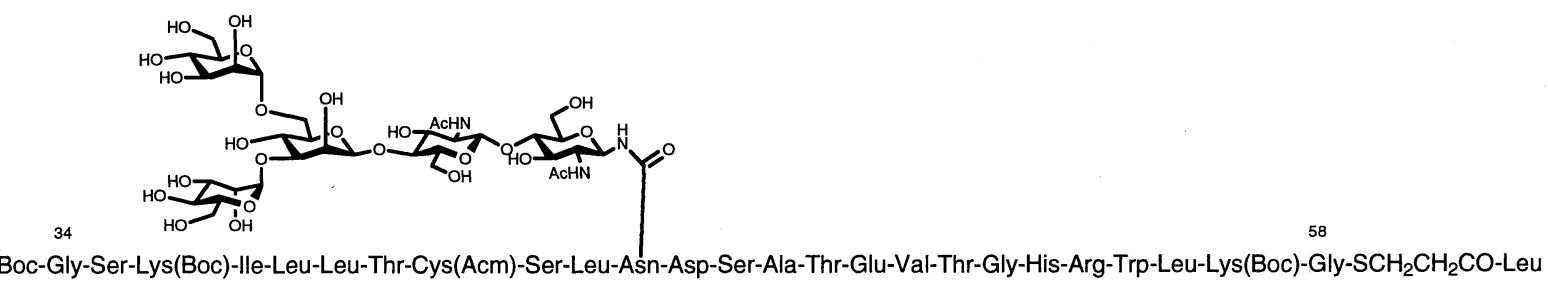

48

Fig. 8. 
Trends in Glycoscience and Glycotechnology Vol.15 No.85 (September 2003) pp.257-273

bination of silyl carbamate and amino acid fluoride in order to suppress the diketopiperazine formation (42). PentasaccharideAsn unit 40 was manually introduced with $60 \%$ efficiency by activation with HATU and DIEA at $50^{\circ} \mathrm{C}$. The peptide thioester thus prepared was detached from the resin with reagent $\mathrm{K}$, debenzylated with low-acidity $\mathrm{TfOH}$ (vide supra), and isolated by HPLC in $1.8 \%$ overall yield. After protection of the amino groups by $\mathrm{N}$-t-buthoxycarbonylation, the resulting segment 48 was reacted with 47 in a similar manner as described above. Full deprotection and subsequent air-oxidation successfully produced the Ig domain carrying pentasaccharide 43 (43). The biological evaluation of this synthetic sample is now under investigation. (Fig. 8)

\section{New Aspects in Solid-Phase Synthesis}

Solid-phase technologies are now essential not only to rapidly assemble the long oligomers of peptide or nucleotide, but also to prepare the diverse molecules in a short time on the basis of combinatorial chemistry. In the course of our project on the synthesis of glycopeptide, we developed new linkers for the solid-phase synthesis. A new allyl ester type linker was designed to obtain the protected glycopeptide segments that can be used for further elongation of the chains both in solution and on resin. Linear connection of this allyl linker to the mild acid-labile amide type resin allows the synthesized peptides to be released from the resin either as the C-terminal carboxylic acids or the allyl ester as shown in the synthesis of 39. The strategy was successfully applied to the synthesis of serglycin core structure molecules. Fmoc glycine was esterified with the allyl linker and attached to the commercial Sieber amide resin. The resin was $\mathrm{N}$-deprotected and then condensed with xylosyl serine derivative 49. The resulting glycopeptide in $\mathbf{5 0}$ was cleaved with $\mathrm{Pd}\left(\mathrm{PPh}_{3}\right)_{4}$ and dimedone in DMSO- $\mathrm{CH}_{2} \mathrm{Cl}_{2}$ to quantitatively produce the glycosylated seryl glycin unit as the C-terminal carboxylic acid. Then resin $\mathbf{5 0}$ was $\mathrm{N}$-deprotected and condensed with the unit (1.5 equiv.) to furnish the tetrapeptide carrying two xylose residues. By repeating this procedure, the glycopeptide chain grew to the octaxylosyl hexadecapeptide. Finally, the synthesized product was released from the resin with $2 \%$ TFA in $\mathrm{CH}_{2} \mathrm{Cl}_{2}$ to give $\mathbf{5 1}$ in $79 \%$ yield. On the other hand, segment coupling in solution was also examined with two octapeptides, one derived by $\mathrm{Pd}$-catalysis and the other by acidic cleavage, to give 51 in $66 \%$ yield (30).

We developed another linker cleavable by fluoride-based condition that is compatible with the Fmoc peptide chemistry. A silyl ether type linker, which connected resin to a hydroxyl group on the peptide or glycopeptide side chain, was designed. Therefore the linker allows the segment condensation at the carboxylic acid site of the linked amino acid in addition to the stepwise elaboration of $\mathrm{N}$-terminus of the peptide (44). The known chlorosilane $\mathbf{5 2}$ was converted into the p-nitro derivative $\mathbf{5 3}$,
最近報告されたジケトピペラジン形成を抑えるためにシリル カーバメートとアミノ酸フルオリドを組み合わせる手法 (42)を 活用することでこの困難は避けられた。5 糖アスパラギンユニッ ト 40 の導入は $50^{\circ} \mathrm{C}$ で HATU と DIEA を用いた活性化によって 手動で行った。このように調製したペプチドチオエステルは reagent $\mathrm{K}$ で樹脂から切り離し low-acidity $\mathrm{TfOH}$ (上記) で脱ベン ジル化して、HPLCにより $1.8 \%$ の通算収率で単離した。アミ ノ基を N-t-ブトキシカルボニル化で保護し、上記同様にセグメ ント 48 を 47 と反応させた。完全脱保護と空気酸化により 5 糖 の結合した Igドメイン 43 生成に成功した(43)。このサンプルの 生物学的評価を現在行っている(図 8)。

\section{D. 固相合成における新しい視点}

固相合成は今やペプチドやヌクレオチドの長鎖オリゴマー を迅速に配列するばかりでなくコンビナトリアルケミストリー を基盤とする短時間での多様な分子構築に無くてはならない技 術となっている。糖ペプチド合成研究の過程でわれわれは固相 合成のための新しいリンカーを開発した。新しいアリルエステ ル型リンカーは得られる保護糖ペプチドのセグメントが溶液中 あるいは樹脂上でさらにその鎖を伸長できるようにデザインし たものである。このアリルリンカーを弱酸で切れるアミド型樹 脂と直線的に結ぶことによって 39 の合成で示したように、合成 されたぺプチドは C-末端がカルボン酸またはそのアリルエステ ルとして樹脂から切り出される。この戦略をセリグリシンのコ ア構造分子の合成に用いることに成功した。Fmoc グリシンをア リルリンカーでエステル化し、市販の Sieberアミド樹脂に結合 した。それはN-脱保護してからキシロシルセリン誘導体 49 と 縮合した。生じた糖ぺプチド $\mathbf{5 0}$ は DMSO- $\mathrm{CH}_{2} \mathrm{Cl}_{2}$ 中で $\mathrm{Pd}\left(\mathrm{PPh}_{3}\right)_{4}$ とジメドンによって切断され、C-末端カルボン酸のグリコシル 化セリグリシンユニットが定量的に生成した。次に樹脂 $\mathbf{5 0}$ － 脱保護し、切り出したユニット( 1.5 当量)と縮合することで二つ のキシロース残基をもつテトラペプチドとした。この操作を繰 り返すことで糖ペプチド鎖はオクタキシロシルヘキサデカペプ チドにまで成長した。最後に生成物は $\mathrm{CH}_{2} \mathrm{Cl}_{2}$ 中の $2 \% \mathrm{TFA} に$ より切断され 51 を $79 \%$ の収率で生成した。一方、パラジウム 触媒で切り出したものと酸で切断したもののふたつのオクタペ プチドを用いて溶液中でのセグメントカップリングも試み、51 を $66 \%$ で得た(30)。

われわれはフルオリドを基盤とする条件下で切断可能であ り Fmoc ペプチド化学に使えるもうひとつのリンカーを開発し た。ペプチドあるいは糖ぺプチド側鎖水酸基に樹脂を結合する シリルエーテル型リンカーをデザインした。そのリンカーを用 いると、ペプチド $\mathrm{N}$-末端でのステップワイズなアミノ酸伸長ば かりでなく、アミノ酸のカルボン酸の位置でセグメント縮合が 可能である(44)。既知のクロロシラン 52 をその p-ニトロ誘導 
which bound the hydroxyl group of the glycothreonine derivative 32 to the glycine-preloaded Wang resin via silyl etherification, reduction of the nitro group, succinamidation, and activation of the carboxylic acid with HBTU-HOBt.

The resulting resin $\mathbf{5 4}$ was deallylated with $\operatorname{Pd}(0)$ catalyst and dimedone in THF and C-terminally chain-elongated with a tripeptide (H-Gly-Val-Ala-OBn) in the presence of the same activating agents. Then the Fmoc group was removed and the glycopeptide was assembled stepwise with glycothreonine, glycoserine (14) and the benzyl and Cbz-protected serine to give 55. Cleavage of the synthesized glycopeptide from the resin was
体 53 に変換し、シリルエーテル化、ニトロ基の還元、コハク酸 アミド化、HBTU-HOBtによるカルボン酸の活性化を経て、糖卜 レオニン誘導体 32 を予めグリシンを担持した Wang 樹脂に結 合した。

こうして出来た樹脂 $\mathbf{5 4}$ は THF 中でパラジウム $(0)$ とジメ ドンを用いた脱アリル化をし、同じ活性化剂とともにトリペプ チド (H-Gly-Val-Ala-OBn)を用いて C-末端への鎖伸長を行った。 次に Fmoc 基を除去し、糖トレオニン、糖セリン (14) およびベ ンジルと Cbz-で保護したセリンを順次用いて糖ペプチドを配列 し55 とした。合成した糖ぺプチドの樹脂からの切断は THF 中

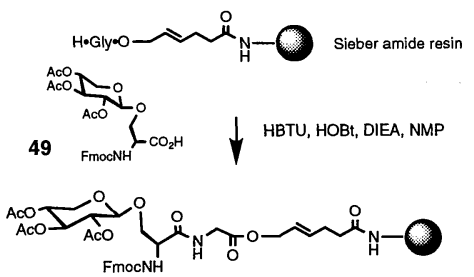

50

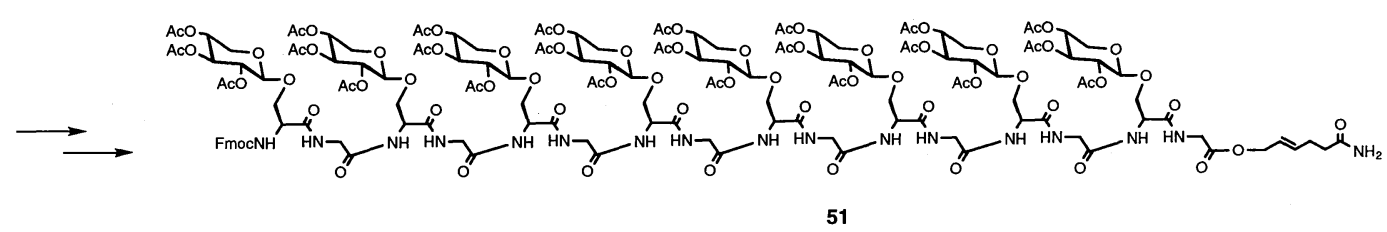

Fig. 9.

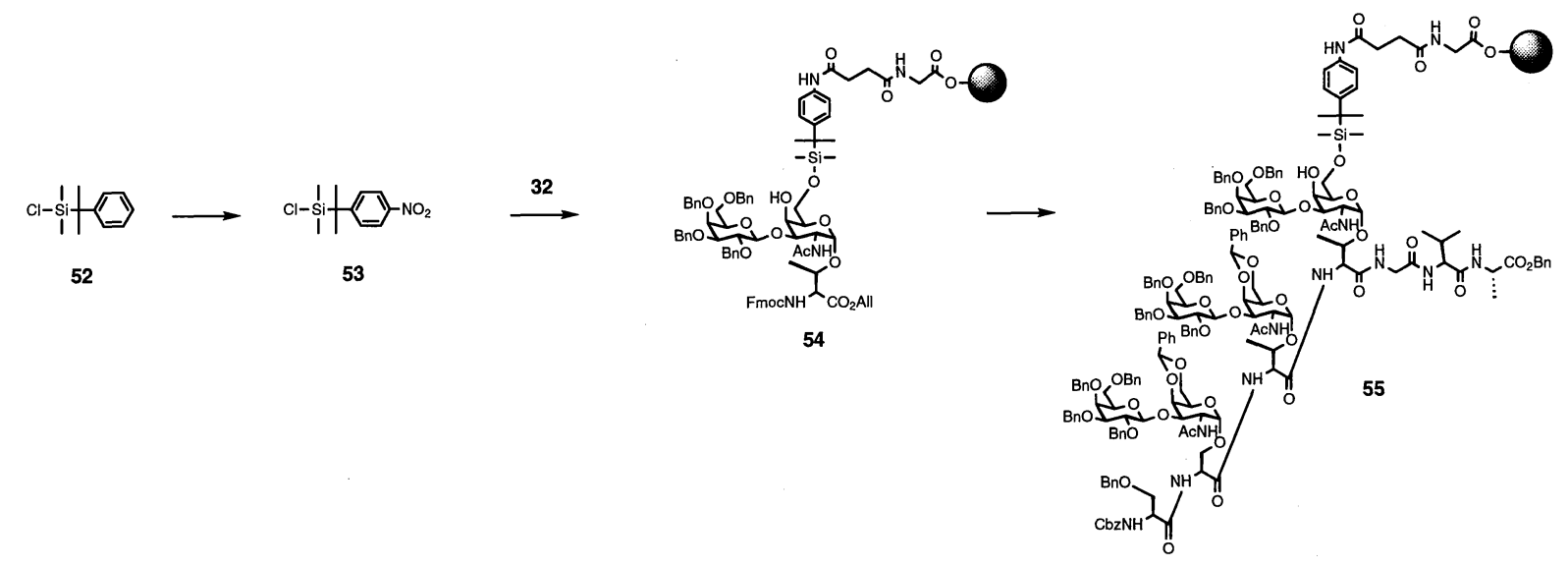

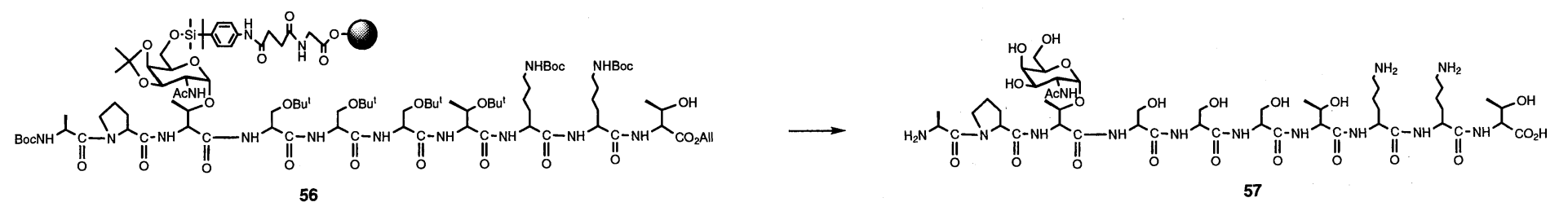

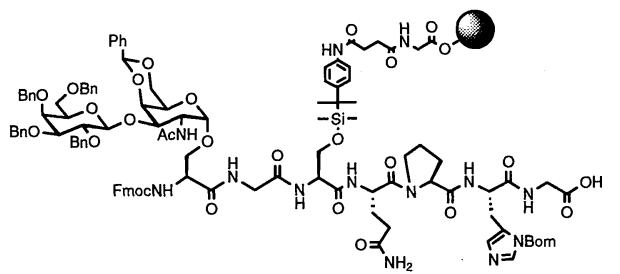

58

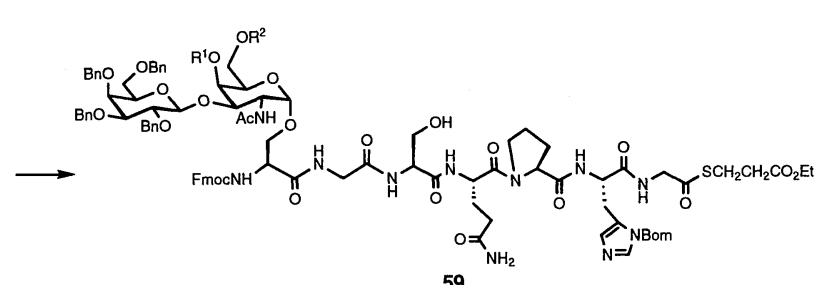

Fig. 10. 
performed with tetrabutylammonium fluoride (TBAF) in THF in the presence of $\mathrm{AcOH}$ to give the protected glycopeptide corresponding to the $\mathrm{N}$-terminal heptapeptide of glycophorin AM in 55\% overall yield (45). The strategy was next applied to the synthesis of the $\mathrm{N}$-terminal segment $\left(\mathrm{Ala}^{1}-\mathrm{Thr}^{10}\right)$ of human interleukin 2. The N-, C- and peptide side chain-protected segment was released from resin $\mathbf{5 6}$ in $86 \%$ yield by fluoridolysis with $\mathrm{CsF}-\mathrm{AcOH}$, while the fully deprotected glycopeptide $\mathbf{5 7}$ was obtained in a comparable yield by acid-catalyzed cleavage (46).

The utility of the silyl linker strategy was further demonstrated by the synthesis of glycopeptide thioester. As described, the peptide thioesters are of practical value in peptide condensation to obtain larger molecules. However, the Fmoc-based preparation of the thioesters on resin has often resulted in low recovery of the synthesized segments because of the instability of the thioester linkage in the basic media. Recently, we proposed an alternative approach to the solid-phase synthesis of glycopeptide thioester. Since our silyl linker method provides the glycopeptide allyl ester on the resin, the C-terminal can be easily manipulated via deallylation. The glycopeptide carboxylic acid 58 was activated and reacted with ethyl 3mercaptopropionate $\left(\mathrm{HSCH}_{2} \mathrm{CH}_{2} \mathrm{CO}_{2} \mathrm{Et}\right)$. The synthesized thioester was detached by acidic cleavage of the silyl ether linkage with $95 \%$ TFA to afford $\mathbf{5 9}$ in $20 \%$ overall yield (47). The thioester segments prepared by this method will be used for the total synthesis of large glycopeptides. (Fig. 9) (Fig. 10)

\section{E. Conclusion and Perspective}

The synthetic methodology for oligosaccharides has now been synchronized with that for oligopeptides and thus enabled us to produce the purposive glycopeptide molecules. Highlighted in this paper are the major outcomes of the synthetic work performed in our research group. The findings of the low acidic conditions for efficient debenzylation of the synthesized glycopeptides enhanced the potential of our benzyl-based protection strategy. On the other hand, Kajihara et al. recently reported a refined solid-phase synthesis of sialoglycopeptide carrying a complex type N-linked oligosaccharide, where a glycoasparagine derived from the enzymatically degraded egg glycoprotein was utilized as the building block (48). Protection was needed only for the carboxylic site of sialic acid residues during the peptide assembly. Some glycopeptides have also been synthesized by other groups under the conditions without protection of the hydroxyl groups (see the references cited in lit. 34). The oligosaccharide-unmasked strategy is attractive in terms of avoiding the loss of product under the deprotective conditions in a basic or acidic medium. In contrast, O-acylation products were formed in substantial quantity, when some amino acid pentafluorophenyl esters were reacted with an amino group linked to the unmasked mannobioside (49). Although this undesired side reaction may or may not be attributed to the prolonged reaction time as noted
眽酸存在下にテトラブチルアンモニウムフルオリド (TBAF) を 用いて行い、グリコホリン $\mathrm{N}$-末端へプタペプチドに相当する保 護された糖ぺプチドが収率 $55 \%$ で生成した (45)。この戦略は次 にヒトインターロイキン 2 の N-末端セグメント $\left(\mathrm{Ala}^{\mathrm{l}}-\mathrm{Thr}^{10}\right)$ の合 成にも適用された。フッ化セシウムと酢酸を用いたフッ素化分解 によってNおよびCそしてペプチド側鎖の保護されたセグメン 卜が樹脂 56 から収率 $86 \%$ で切り出され、酸触媒による切断反 応を行うと同様の収率で完全脱保護体 $\mathbf{5 7}$ が得られた(46)。

このシリルリンカー戦略の有用性はさらに糖ぺプチドチオ エステル合成によって示された。すでに述べたようにペプチド チオエステルは大きな分子を得るためのペプチド縮合において 実用的な価值が高い。しかしながら Fmoc を基盤とする樹脂上 でのチオエステルの調製はしばしば合成セグメントの回収がわ るい、それは塩基性媒体中でのチオエステル結合の不安定さが 原因となる。最近われわれは糖ペプチドチオエステル固相合成 のためにもう一つのアプローチを提案した。われわれのシリル リンカー法では樹脂上に糖ペプチドアリルエステルがつくられ るため、脱アリル化すればそのC-末端は容易に細工出来る。糖 ペプチドカルボン酸 58 を活性化して3-メルカプトプロピオン 酸エステル $\left(\mathrm{HSCH}_{2} \mathrm{CH}_{2} \mathrm{CO}_{2} \mathrm{Et}\right)$ と反応した。合成したチオエステ ルはそのシリルエーテル結合を $95 \%$ TFA を用いて酸分解し 59 が $20 \%$ の通算収率で得られた(47)。この方法で合成されるチオ エステルセグメントを用いた大きな糖ぺプチドの全合成が期待 される(図 9) (図 10)。

\section{E. 結論と展望}

オリゴ糖合成の方法論は今やオリゴペプチドのそれとすり 合わされて、意図した糖ぺプチド分子をつくることが可能と なってきた。この論文でとりあげたのはわれわれの研究グルー プで行った合成研究の成果である。合成糖ぺプチドの効率的な 脱ベンジルのための低酸性条件の発見はわれわれのベンジルを 基盤とする戦略の可能性を強化することとなった。

一方、最近梶原らは卵の糖タンパク質を酵素的に分解して つくられる糖アスパラギンをビルディングブロックとして用い て、複合型の $\mathrm{N}$-結合型糖鎖をもつシアロ糖ぺプチドの巧みな固 相合成を報告している(48)。彼等はぺプチドを配列する間、シア ル酸残基のカルボキシル部のみを必要とした。この他にも水酸 基の保護なしの状態でいくつかの糖ペプチドの合成がすでにな されてきている (文献 33 中の引用参照)。塩基や酸媒体を用いた 脱保護時の生成物の損失を避ける意味で糖鎖無保護の戦略は魅 力的である。一方、われわれは最近無保護マンノビオシドに結 合したアミノ基をアミノ酸ペンタフルオロフェニルエステルと 反応した際、生成物のかなりの量が O-アシル化されているのを 経験した(49)。この望まぬ副反応が梶原の論文に指摘されている ような反応時間を長くしたためであったかどうかはわからない が、樹脂上で配列するオリゴマーが長ければ長いほど O-アシル 化のリスクは大きくなるだろう。 
in Kajihara's paper, the potential risk of O-acylation may become greater when the longer oligomer is assembled on the resin.

Chemoenzymatic procedure is another method of choice and has been applied extensively to the synthesis of glycoconjugate (50-53). The ready availability of the sialyltransferases has shortened our synthetic steps to the core 2 hexasaccharide. Application of the enzymatic technologies with glycosyltransferases, glycosidases and endoglycosidases (54-56) will enhance the potential of chemically synthesized substrates for the complex glycopeptides.

In peptide chemistry, ligation of the segments is essential to gain access to the large peptide molecules. The necessary peptide thioesters have successfully been prepared by the Boc solid-phase protocol. The Fmoc procedure compatible with the presence of acid labile glycosides is not yet entirely free of the problem of low recovery of the product from the resin. Development of a new practical method for the preparation of peptide thioester is desirable. On the other hand, the native chemical ligation method $(57,58)$ is a very promising technology for the total or semisynthesis of glycoproteins of large molecular size, especially when that is combined with the use of expressed protein convertible to the thioester through an intein-mediated protein splicing mechanism (59). Although the ligation required the $\mathrm{N}$-terminal cystein for the amino component, several $\mathrm{N}$ - and O-linked glycopeptides have been synthesized with this device (60-62).
化学酵素的合成はもう一つの選択肢であり、複合糖質の合 成に広く使われてきている(50-53)。シアル酸転移酵素が容易に 入手できることでわれわれのコア 2 型 6 糖合成の工程が短縮さ れた。糖転移酵素や糖加水分解酵素、そしてエンド加水分解酵 素の応用 (54-56) は、複雑な糖ぺプチドのために合成基質が可 能であることを強調するものである。

ペプチド化学において大きなペプチド分子を作ろうとすれ ばセグメントのライゲーションが必須である。それに必要なぺ プチドチオエステルはこれまで Boc 固相法でうまく調製されて きた。酸に不安定なグリコシドに合う Fmoc 法はまだ生成物の 樹脂からの低回収の問題が完全には解決されていない。ぺプチ ドチオエステルを調製するための新しい実用的な方法の開発が 望まれる。一方 native chemical ligation 法 $(57,58)$ は、インテイ ン関与のタンパク質スプライシング機構で発現タンパク質をチ オエステルへ変換する技術 (59) と組み合わせることによって、 大きな分子サイズの糖タンパク質の全合成や半合成の技術とし て大変有望である。そのライゲーションではアミノ成分として N-末端にシステインが必要であるという制約はあるが、すでに この方法でいくつかの N-および O-結合型糖ぺプチドが合成さ れている(60-62)。

\section{References}

1. Lavielle, S., ling, N.C., and Guillemin, R.C. (1981) Carbohydr. Res. 89, 221-228

2. Hojo, H., and Nakahara, Y. (2000) Curr. Protein \& Pept. Sci. 1, 23-48

3. Koeller, K.M., and Wong, C.-H. (2001) In Glycoscience (Fraser-Reid, B., Tatsuta, K., and Thiem, J. eds.) pp. 2305-2352, Springer-Verlag, Berlin

4. Davis, B.D. (2002) Chem. Rev. 102, 579-601

5. Kihlberg, J. (2000) In Fmoc Solid Phase Peptide Synthesis (Chan, W.C., and White, P.D. eds.) pp.195-213, Oxford University Press, New York

6. Kunz, H. (1997) In Preparative Carbohydrate Chemistry (Hanessian, S. ed.) pp 265-281, Marcel Dekker, New York

7. Boons, G.J. and Polt, R.L. (1998) In Carbohydrate Chemistry (Boons, G. J. ed.) pp 223-242, Blackie Academic \& Professional, London

8. Seitz,O., Heinemann, I., Mattes, A. and Waldmann, H (2001) Tetrahedron 57, 2247-2277

9. Mizuno, M. (2001) Trends Glycosci. Glycotechnol. 13, 11-30

10. lijima, H., and Ogawa, T. (1988) Carbohydr. Res. 172, 183-193

11. Iijima, H., and Ogawa, T. (1989) Carbohydr. Res. 186, 95-106

12. Iijima, H., and Ogawa, T. (1989) Carbohydr. Res. 186, 107-118

13. Ito, Y., and Ogawa, T. (1988) Tetrahedron Lett. 29, 3987-3990

14. Kanie, O., Kiso, M., and Hasegawa, A. (1988) J. Carbohydr. Chem. 7, 501-506

15. Nakahara, Y., Iijima, H., Shibayama, S., and Ogawa, T. (1990) Tetrahedron Lett. 31, 6897-6990; (1991) Carbohydr. Res. 216, 211-225

16. Iijima, H., Nakahara, Y., and Ogawa, T. (1992) Tetrahedron Lett. 33, 7907-7910

17. Nakahara, Y., Iijima, H., and Ogawa, T. (1994) Tetrahedron Lett. 35, 3321-3324

18. Nakahara, Y., Iijima, H., and Ogawa, T. (1994) Carbohydr. Lett. 1, 99-106

19. Nakahara, Y., Iijima, H., and Ogawa, T. (1994) ACS Symp. Ser. 560, 249-266

20. Nakahara, Y., Nakahara, Y., and Ogawa, T. (1996) Carbohydr. Res. 292, 71-81

21. Nakahara, Y., Nakahara, Y., Ito, Y., and Ogawa, T. (1997) Tetrahedron Lett. 38, 7211-7214; (1998) Carbohydr. Res. 309, 287-296

22. Ando, S., Nahara, Y., Ito, Y., Ogawa, T., and Nakahara, Y. (2000) Carbohydr. Res. 329, 773-780

23. Singh, L., Nakahara, Y., Ito, Y., and Nakahara, Y. (1999) Tetrahedron Lett. 40, 3769-3772; (2000) Carbohydr. Res. 325, 132-142

24. Paulsen, H, Rauwald, W., and Weichert, U. (1988) Liebigs Ann. Chem. 75-86

25. Xia, J., Alderfer, J.L., and Matta, K.L. (2000) Bioorg. Med. Chem.. Lett. 10, 2485-2487

26. Huang, B.-G., Jain, R. K., Locke, R. D., Alderfer, J. L., Tabaczynski, W. A., and Matta, K. L. (2000) 41, 6279-6284

27. Watabe, J., Singh, L., Nakahara, Y., Ito, Y., Hojo, H., and Nakahara, Y. (2002) Biosci. Biotechnol. Biochem. 66, 1904-1914 
28. Takano, Y., Habiro, M., Someya, M., Hojo, H., and Nakahara, Y. (2002) Tetrahedron Lett. 43, 8395-8399

29. Takano, Y., Kojima, N., Nakahara, Y., Hojo, H., and Nakahara, Y. (2003) Tetrahedron 59, 8415-8427

30. Nakahara, Y., Ando, S., Itakura, M., Kumabe, N, Ito,Y. and Nakahara, Y. (2000) Tetrahedron Lett. 41, 6489-6493

31. Nakahara, Y., Ando, S., Ito, Y., Hojo, H., and Nakahara, Y. (2001) Biosci. Biotechnol. Biochem. 65, 1358-1368

32. Kosch, W., März, J., and Kunz, H. (1994) React. Polym. 22, 181-194.

33. Seitz, O., and Kunz, H. (1997) 62, 813-826

34. Ichiyanagi, T., Takatani, M., Sakamoto, K., Nakahara, Y., Ito, Y., Hojo, H., and Nakahara, Y. (2002) Tetrahedron Lett. 43, 3297-3300

35. Seifert, J., Lergenmüller, M., and Ito, Y. (2000) Angew. Chem. Int. Ed. 39, 531-534

36. Matsuo, I., Nakahara, Y., Ito, Y., Nukada, T., Nakahara, Y., and Ogawa, T. (1995) Bioorg. Med. Chem. 3, 1455-1463

37. Guo, Z.-W., Nakahara, Y., Nakahara, Y., and Ogawa, T. (1997) Angew. Chem. Int. Ed. 36, 1464-1466; (1997) Bioorg. Med. Chem. 5, 19171924

38. Hojo, H., and Aimoto, S. (1991) Bull. Chem. Soc. Jpn. 64, 111-117

39. Hojo, H., Watabe, J., Nakahara, Y., Nakahara, Y., Ito, Y., Nabeshima, Y., and Toole, B.P. (2001) Tetrahedron Lett. 42, 3001-3004

40. O'Connor, S. E., and Imperiali, B. (1998) Chem. \& Biol. 5, 427-437

41. Li, X., Kawakami, T. and Aimoto, S. (1998) Tetrahedron Lett. 39, 8669-8672

42. Sakamoto, K., Nakahara, Y., and Ito, Y. (2002) Tetrahedron Lett. 43, 1515-1518

43. Hojo, H., Haginoya, E., Matsumoto, Y., Nakahara, Y., Nabeshima, K., Toole, B. P., and Watanabe, Y. (2003) Tetrahedron Lett., 44, $2961-2964$

44. Nakamura, K., Hanai, N., Kanno, M., Kobayashi, A., Ohnishi, Y., Ito, Y. and Nakahara, Y. (1999) Tetrahedron Lett. 40, 515-518

45. Nakamura, K., Ishii, A., Ito, Y. and Nakahara, Y. (1999) Tetrahedron 55, 11253-11266

46. Ishii, A., Hojo, H., Kobayashi, A., Nakamura, K., Nakahara, Y., Ito, Y., and Nakahara, Y. (2000) Tetrahedron 56, 6235-6243

47. Ishii, A., Hojo, H., Nakahara, Y., Ito, Y., and Nakahara, Y. (2002) Biosci. Biotechnol. Biochem. 66, 225-232

48. Yamamoto, N., Ohmori, Y., Sakakibara,T., Sasaki, K., Juneja, L. R., and Kajihara, Y. (2003) Angew. Chem. Int. Ed. 42, 2537-2540

49. Tanaka, Y., Nakahara, Y., Hojo, H., and Nakahara, Y. (2003) Tetrahedron 59, 4059-4067

50. Fitz, W., and Wong, C.-H. (1997) In Preparative Carbohydrate chemistry (Hanessian, S. ed.) pp. 485-504, Marcel Dekker, New York

51. Schuster, M., Wang, P, Paulson, J. C. and Wong, C.-H. (1994) 116, 1135-1136

52. Unverzagt, C., Kelm, S., and Paulson, J.C. (1994) Carbohydr. Res. 251, 285-301

53. Ajisaka, K. (2001) Trends Glycosci. Glycotechnol.12, 305-318

54. Yamamoto, K., Fujimori, K., Haneda, K., Mizuno, M., Inazu, T., and Kumagai, H. (1998) Carbohydr. Res. 305, 415-422

55. Haneda, K., Inazu, T., Mizuno, M., Iguchi, R., Yamamoto, K., Kumagai, H., Aimoto, S., Suzuki, H.. and Noda, T. (1998) Bioorg. Med. Chem. Lett. 8, 1303-1306.

56. O'connor, S. E., Pohlman, J., Imperiali, B., Saskiawan, I., and Yamamoto, K. (2001) J. Am. Chem. Soc. 123, 6187-6188

57. Dawson, P. E., Muir, T. W., Clark-Lewis, I., and Kent, S.B.H. (1994) Science, 266, 776-779

58. Dawson, P. E., and Kent, S.B.H. (2000) Annu. Rev. Biochem. 69, 923-960

59. Muir, T. W., Sondhi, D. and Cole. P. A. (1998) Proc. Natl. Acad. Sci. USA, 95, 6705-6710

60. Tolbert, T. J., and Wong, C.-H. (2000) J. Am. Chem. Soc. 122, 5421-5428

61. Grogan, M. J., Pratt, M. R., Marcaurell, L.A., and Bertozzi, C.R. (2002) Annu. Rev. Biochem, 71, 593-634

62. Miller, J. S., Dudkin, V.Y., Lyon, G.J., Muir, T.W., and Danishefsky, S.J. (2003) Angew. Chem. Int. Ed. 42, 431-434

Received on August 4, 2003, accepted on October 2, 2003

\section{Profile of the Author}

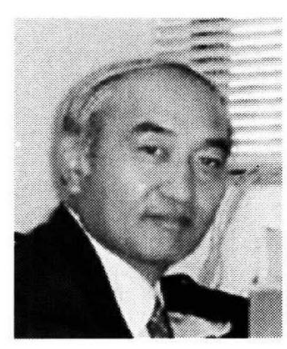

Yoshiaki Nakahara received his B. S. C (1967) and Ph. D. (1972) in organic chemistry from the Faculty of Agriculture, the University of Tokyo, under the guidance of Professors Masanao Matsui and Kenji Mori, working on the total synthesis of steviol, the aglycon of stevioside. In 1972, he joined Professor M. Matsui's laboratory in RIKEN (The Institute of Physical and Chemical Research) as a staff scientist. From 1976, he spent two years in Professor Gilbert Stork's group at Columbia University as a postdoctoral fellow, working on the total synthesis of cytochalasin B, a macrolide antibiotic. Since he returned to RIKEN and joined the laboratory directed by Professor Tomoya Ogawa, he has been studying the carbohydrate-based synthesis of natural products, and syntheses of oligonucleotides, plant oligosaccharides and glycopeptides. From 1996 to 2001, he has been director of the CREST project on the studies of new synthetic methods of oligosaccharides and large glycopeptides sponsored by Japan Science and Technology Corporation. In 1997, he was appointed to a professorship in organic chemistry at Tokai University. 